\title{
SIYYASI MITINGLERIN SOSYO-POLITIKK ANALIZI \\ Adalet ve Kalkınma Partisi ile Milliyetçi Hareket Partisi Mitingleri Örneği
}

SOCIO-POLITICAL ANALYSIS OF POLITICAL RALLIES

The Sample of Justice and Development Party and Nationalist Movement Party

\section{СОЦИО-ПОЛИТИЧЕСКИЙ АНАЛИЗ ПОЛИТИЧЕСКИХ МИТИНГОВ}

На примере митингов партиев “Справедливость и развитие” и "Партия национального движения"

\section{İhsan KURTBAŞ*}

\section{Öz}

Mitingler, [siyasal] katılımın en önemli enstrümanlarından biridir. Ancak Türkiye'de seçim mitinglerinin sosyopolitik açıdan irdelendiği başka bir çalışmaya rastlanmamış olması bu önemli alanın/aracın yadsındığı anlamına gelmektedir. Teorik ve ampirik iki bölümden oluşan çalışmanın ampirik kısmı, yerel seçimler öncesinde Adalet ve Kalkınma Partisi (Ak Parti) ile Milliyetçi Hareket Partisi (MHP) mitingine katılan 300 seçmene anket kullanılarak yapılmıştır. Temel amaç siyasi mitinglere kimin, neden, hangi sıklıkla katıldığı gibi farklı değişkenleri belirlemek ve etkilerini irdelemek; katılanların ne kadarının seyirci, ne kadarının taraftar olduğunu anlamak; mitingdeki seçmenin ruh haline ilişkin psikopolitik bir tahlile ulaşmak ve neticede mitinglerin sosyopolitik analizini yapmaktır.

Elde edilen verilerin bazılarına göre mitinge katılanların yarısından çoğu mitingin yapılacağı yer ve zaman gibi bilgileri televizyondan edinmektedir. İnsanlar, mitinglere, daha çok partisine destek vermek, partinin genel başkanını görmek, zaman geçirmek/merak gidermek için gitmektedir. Mitinge katılanlardan yaklaşık her yüz kişiden dördünün tercih ve kararları olumsuz yönde değişmiştir. Mitinglere il merkezinden kadınlar; merkez ilçe ve il dışından erkekler daha çok katılmaktadır. Erkekler, ileri yaştakiler ve eğitim seviyesi yüksek kimseler mitinglere daha fazla ve sık katılmaktadır. Mitinglere ev hanımları en az katılan meslek grubunu oluştururken, en çok katılanlar, kamu çalışanlarıdır. Ak Parti mitingine daha çok ev hanımları, MHP mitingine ise daha çok kamu personeli katılmıştır. MHP mitingine katılanların eğitim düzeyi daha yüksektir. MHP mitinginde taraftar; Ak Parti mitinginde ise izleyici oranı daha yüksektir. Katılımcılar AK parti mitingine daha çok genel başkanı görmek, MHP mitingine ise partisine destek vermek için katılmıştır. MHP mitingdekiler içinde bulundukları ruh halini daha çok öfkeli ve cesaretli; Ak Parti mitingindekiler ise umutlu ve gururlu şeklinde tarif etmiştir.

\footnotetext{
* Yrd. Doç. Dr., Ardahan Üniversitesi İ̈BF, Siyaset Bilimi ve Kamu Yönetimi Bölümü Öğretim $\ddot{U y e s i}$,

Ardahan Ekonomik ve Sosyal Uygulama ve Araştırma Merkezi (ARESAM) Müdürü, kurtbasihsan@hotmail.com
} 
Anahtar Kelimeler: Siyasal Katılım, Kamuoyu, Miting, Adalet ve Kalınma Partisi (Ak Parti), Milliyetçi Hareket Partisi (MHP)

\section{ABSTRACT}

Rally is one of the most important instruments of the [political] participation. However, considering that it has not been found in another study in which the election rallies are examined sociopolitically in Turkey means that this important instrument/field is denied. The study consists of theoretical and empirical parts. The empirical part includes a questionnaire to 300 voters that attended to the rallies of Justice and Development Party and Nationalist Movement Party before local elections. The main purpose is to determine different variables involving those who attend to political rallies, why and how often; to examine their effects; to understand how much of them is spectator or supporter; to obtain a psycho- political analysis related to the mood of voters in rally and eventually to carry out a socio-political analysis of the rally.

According to some of the obtained data, more than half of the attenders that attend to the rally obtain information about the rally place and the beginning time of it from televisions. People attend to the rallies mostly to give support to their parties, to see the party leader, to spend time or satisfy their curiosity. About four out of every hundred people who attended to the rally changed their preferences and judgments negatively. The attenders to the rallies are mostly women from city centres, and men from central district and outside the province. Men, elderly ones and those with high levels of education attend more and more often to the rallies. While the housewives attend to the rallies at the very least, the public employees are at the very most. The housewives attend mostly to the rallies of Justice and Development Party and the public employees mostly to those of Nationalist Movement Party. The education level of attenders for Nationalist Movement Party is higher. The rate of supporters is higher in the rallies of Nationalist Movement Party. However, it is the rate of spectators that is higher in the rallies of Justice and Development Party. The attenders took part in the rally of Justice and Development Party mostly to see the party leader; on the other hand, it was mostly to give more support to their party in the that of Nationalist Movement Party. Those in the rally of Nationalist Movement Party identified their mood mainly as angry and courageous. However, it was defined as happy and proud for those in the rally of Justice and Development Party.

Keywords: Political Attendance, Public Opinion, Rally, Justice and Development Party, Nationalist Movement Party

\section{АННОТАЦИЯ}

Митинги, важнейшие инструменты политического участия. Однако, при изучении митингов, связанных с выборами, с точки зрения социополитического анализа, выявляется, что эта тема как то отрицается и не изучена по научному. Предыдущая статья состоит из двух теоретического и эмпирического частей. Эмпирическая часть была изучена на основе анкетных данных, составленных во время предвыборной кампании партиев “Справедливость и развитие" и "Партия национального движения”. Были опрошены 300 избирателей с обеих сторон. Основная цель работы, изучение причины митингов, частоты участия в нём , личности участников, род митингов и его воздействие, опроделение численности 
настоящих участников и простых зрителей, психо-политический анализ душевного состояния участников митинга и социо-политический анализ самых митингов.

По итогам разных данных, более половины участников митинга получают информацию о месте и времени состояния митингов по телевидению. Большинство людей туда ходят для поддержки своей партии, чтобы посмотреть на лидера партии или же удовлетворить свои интерессы. Из ста участников митинга, у четверых меняются предпочтения и решения в отрицательную сторону. На митингах, из региональных центров, в основном ходят женщины, а из районных центров и вне региона, мужское население. Участники митинга из мужского пола, в основном являются пожылого возраста с хорошим образованием. В митингах домохозяйки почти не участвуют. Из женского пола участниками являются работники общественных организации. На митингах партии “Справедливость и развитие” больше всех ходят домохозяйки, а на митингах "Партии национального движения” работники общественных организации. Участники митнигов "Партии народного движения" более образованы. На митингах "Партии национального движения" больше ходят сторонники этой партии, а на митингах“Справедливости и развития”зрители. На митингах партии “Справедливость и развитие” ходят для того, чтобы увидеть лидера партии, а на митингах "Партии национального движения”, чтобы поддержать партию. У участников митинга "Партии национального движения" высокое яростное и мужественное духовное положение, а у участников партии “Справедливость и развитие” - высокая надежда и гордость.

Ключевые слова: политическое участие, общественность, митинг, "Партия справедливости и развития”, “Партия национального движения”.

\section{GíRiş}

Çağımız, insan düşüncesinin sürekli olarak değiştiği hassas ve buhranlarla dolu bir devre içinde bulunmaktadır. Keşmekeşliğin ve karmaşanın zorunlu bir durum aldığı böyle bir dönemden ilerde nelerin meydana geleceğini şimdiden söylemek mümkün değildir. Bizim toplumumuzun yerini alacak toplumlar hangi temel fikirler üzerine kurulacaktır? Bunu henüz bilmiyoruz. Fakat şimdiden tahmin edebiliriz ki, bu toplumların oluşmasında artık yeni çağda egemen olan yeni bir güç yer alacaktır: Kalabalıkların gücü... Le Bon (1997: 10), 'Kitleler Psikolojisi' adlı kitabında, 'kalabalıkların gücü' vurgusunu yaparken adeta modern siyasette kolektif olmanın gereği ve önemine gönderme yapmaktadır. Zira günümüz siyasetinde kamuoyu oluşturmanın doğrudan ve en etkili yolu kolektif olmaktır. Hatta bu gerçeğin bilincinde olan küçük; ancak ateşli kolektif topluluklar, toplumun daha büyük kesimine nazaran siyasi kararlara daha çok sirayet edebilmekte ve uygulamalarda daha öncelenebilmektedirler. Bir toplumda, insanların, siyasal katılımlarını gerçekleştirirken, hangi yöntemi tercih ettikleri ve hangi enstrümanları-hangi sıklıkla kullandıkları ise hem o toplumun siyasal kültürünün göstergesi olması bakımından, hem de siyasa üzerinde yarattığı etki açısından son derece önem taşımaktadır.

Bir siyasal katılım enstrümanı olarak mitingler, seçimler öncesinde en sık başvurulan katılım çeşitlerinden biridir. Günümüzde mitingler sadece "kamuoyu oluşturmak için değil; rakiplere göz dağı vermek - gövde gösterisi yapmak, siyaseten bir mesaj iletmek, taraftarlarında yalnız olmadıkları, bilakis çok oldukları hissiyatını yaratmak, kitle iletişim araçları vasıtasıyla toplumun değişik kesimlerine iddia ve ideallerini iletmek, seçmen 
üzerinde Bandwagon Etkisi ${ }^{1}$ yaratmak son kertede toplumun rızasını almak gibi çok sayıda amaca hizmet eder. Bu açıdan mitingler siyasi aktörlerle seçmenlerin yüz yüze/anlık iletişim kurulduğu alanlar-araçlar olmanın ötesinde, sonradan yaratacağı intibaı ve imaja yönelik birer mizansen, partilerin/adayların mevziler kazanıp kaybettiği adeta birer savaş alanıdır. Böylesine önemli bir siyasal iletişim aracının ve katılım enstrümanın sosyo-politik açıdan analizinin ortaya konulması hem siyaset bilimi literatürüne yapacağı katkı açısından, hem de siyasal aktörlerin seçmeni daha yakından tanıması bakımından önemlidir.

\section{TEORIK ÇERÇEVE}

\subsection{Siyaset Kavramı}

En eski medeniyetler doğmadan önce dahi insan asla (bir insanın bir diğer insanla hiçbir ilişkisinin olmadığı derecede) tek başına yaşamamıştır. İnsanların yaşam tarzı daima topluma benzer bir yapıda olmuştur. İnsanı siyasal bir hayvan, yani toplumsal bir hayvan olarak tarif eden Aristo'tan beri bu, açıkça bilinmektedir (Mosca, 2013: 10). Modern siyaset/politika tanımlarının beslendiği bu gerçeği ve günümüze kadar yapılan siyaset tanımlama çabalarını hızla geçecek olursak; günümüzde kendimizi [karşıt ve zıt görüşte] ideolojik ve entelektüel siyaset tanımlarının istilasına uğramış bir çağda bulmaktayız.

En geniş anlamıyla "insanların hayatlarını düzenleyen genel kuralları yapmak, korumak ve değiştirmek için gerçekleştirdikleri faaliyetler (Heywood, 2007: 22)" olarak tanımlanan politika ile siyaset kavramları, gündelik hayatta birbirinin yerine kullanılmaktadır. Ancak iki kavramında etimolojisi ve kültürel kaynakları oldukça farklıdır. Politika, köken açısından Yunanca bir kelimedir. Eski Yunan'da devlete yani şehre-siteye ilişkin işler ${ }^{2}$ anlamında kullanılmaktaydı. Arapça 'at eğitimi' anlamına gelen siyaset ise at bakıcısı olan 'seyis' kelimesi ile aynı köktendir.

Günümüzde politika “düşünsel yol/yöntem” anlamına gelecek kararlar ve uygulamalara yönelik olarak da kullanıldığından bu çalışmada 'siyaset' sözcüğü tercih edilecektir. $\mathrm{Bu}$ çerçevede siyasetle ilgili en yaygın tanımlardan biri, iktidar ilişkisinin dayandığı "güç" üzerinden yapılır. Weberyan değerlendirmede, birinin bir başkasının muhalefetine rağmen ona bir şeyler yaptırma iradesi olan güç, siyaseten bir tarafın/kişinin diğer taraf/kişiler üzerinde egemenlik kurmasıdır. Zira "siyaset, taraf tutmaktır; tarafların olması ve kendi çıkarlarının gerçekleştirilmesi için ortak belirlenmiş yasalar içerisinde mücadele etmektir. Taraflar yoksa siyasette yok demektir (Çetin, 2012: XI)”. Nitekim siyaset, farklı siyasal enstrümanları kullanarak iktidarı ele geçirmek ve elde tutmaya yönelik bir mekanizma ve mücadele/uzlaşma sürecidir.

Diğer taraftan bazı görüşler ise siyaseti, 'belli bir zamanda, egemen üretim biçimleri ve ilişkilerinin korunması ve geliştirilmesi' şeklinde bir uğraş olarak tanımlar. Buna göre siyaset üretim dışında kalan, ancak üretimin sürdürülebilmesi ve geliştirilebilmesi için toplumsal çapta yürütülmesi zorunlu olan işlerin toplamıdır. Bu süreçte üretim güçleri ile

${ }^{1}$ Siyaset Alanında: Kazananın peşine takılma eğilimi; Ekonomi Alanında: Ne kadar fazla insan hâlihazırda piyasadaki bir ürüne sahipse o ürüne olan talep o kadar artar.

${ }^{2}$ Eski Yunan'da politikaya ilişkin sözcükler şunlardır: Polis; Devlet, Politika: Siyasal işlerşeyler, Politike: Devlet yönetme sanat, Siyaset sanat, Politis: Vatandaş. Politeia: Devlet, Anayasa, Cumhuriyet. Politikos: Devlet adamı 
üretim ilişkileri arasında çelişki yoksa siyaset uyuşumcu, varsa kavgacı olur (Eroğlu, 2012a: 19).

$\mathrm{Bu}$ tanımlar ve türevlerinde dikkat çeken husus; siyasetin biri çatışma/kavga/mücadele diğeri uzlaşma/mutabakat/diyalog olmak üzere iki yönünün olduğudur. Nitekim Kapani’ye göre (2009: 17-19) siyasete ilişkin yapılan tüm tanımlamalar başlıca iki değişik ve karşıt görüş etrafında toplanır: "Bunlardan ilki siyaset, asıl konusu toplumdaki değerlerin paylaşılması, hedefi ise, iktidarın ele geçirilmesi ve onun sağladığı yararların (nimetlerin) paylaşılmasından doğan bir çatışma, bir mücadele ve bir kavgadır. Karşıt temel görüşü temsil eden düşünürlere göre ise siyasetin amacı her şeyden önce toplumda bütünlüğü sağlamak, özel çıkarlara karşı koyarak genel yararı ve insanların 'ortak iyiliğini' gerçekleştirme, herkesin yararına olan bir toplum düzenini kurma çabasıdır”.

Bütün siyaset tanımlarında şu dört temel karakteristik özelliğe rastlandığından söz edilir (Emiroğlu, 2006: 8-9): “(a) Politika, zaman ve mekân bakımından evrensel ve sürekli niteliktedir. (b) Politika öz olarak toplumdaki değerlerin dağıtımıyla ilgili bir görüş ve çıkar çatışması ve bir iktidar mücadelesidir. (c) Politika sadece bir çatışma değil, aynı zamanda bir uzlaşmadır. (d) İnsanların yaşayışlarını yakından ilgilendiren ve etkileyen bir faaliyet olarak amacı, insanların kendi yaşantılarını daha iyiye götürmektir". Benzer şekilde Heywood'da (2007: 23) siyasete ilişkin tanımlarda dört temel başlığın karşımıza çıktığını ifade eder: (a) Hükümet etme sanatı olarak siyaset, (b) Kamusal işler (kamu meseleleri) olarak siyaset, (c) Uzlaşma ve mutabakat olarak siyaset, (d), İktidarın ve kaynakların dağıtımı olarak siyaset”. Görüldüğü üzere siyaset devlet bilimi, iktidar bilimi/mücadelesi, değerlerin dağıtımı, kamusal işler olarak algılandığından, gündelik dilde devlet yönetimine katılma ile siyasal katılmanın aynı anlamlarda kullanıldığı durumlarla karşılaşırız. Bu bakımda siyasette siyasal katılmanın işlevi ve önemi son derece büyüktür.

\subsection{Siyasal Katılım}

\subsubsection{Siyasal Katılmanın Tanımı ve Tarihsel Gelişimi}

Devletin yaklaşık beş bin beş yüz yıllık bir geçmişi bulunmasına karşılık, siyasal katılma görece yeni bir olgudur. Gerçi zamanımızdan yaklaşık yirmi üç ila yirmi altı yüzyıl önce eski Yunan'da, Roma'da ya da Çin'de olsun, ilk siyasal katılma deneyimlerinin karşımıza çıktığı doğrudur. Siyasal katılma esas olarak, İngiliz (17yy), Amerikan (18yy), Rus (20yy) devrimlerinin ve II. Dünya Savaşı'nı izleyen büyük siyasal uyanış ile yaygın bağımsızlık hareketinin ürünüdür (Eroğlu, 2012b: 195-196). Nitekim siyasal katılma modernleşmeyle birlikte kentleşme oranının arttığ toplumlarda ortaya çıkmıştır. Modernleşmenin siyasal yaşam üzerindeki etkisi çeşitli biçimlerde sınıflandırılsa da üç tür özelliğin altını çizmekte fayda vardır. İlk olarak siyasal modernleşme otoritenin ussallaşmasına ve çok sayıda geleneksel, dinsel, aile veya etnik siyasal otoriteler yerine bir tek dünyevi siyasal otoritesinin geçmesini; ikinci olarak siyasal modernleşme eskiden beri var olan siyasal işlevlerin yeniden farklılaşması ve bu işlevleri görmek için yeni uzmanlaşmış yapıların ortaya çıkmasını; üçüncü olarak ise, toplumsal grupların siyasete artan oranda katılmalarını ifade eder (Kahraman, 2011: 58-59). Yakın zamanda çağımıza damgasını vuran bu dört devrim ve siyasal modernleşmeyle birlikte modern siyaset doğmuştur. Böylece modern siyaset 'Tanrı yerine insanı, gelenek yerine kuralları, metafizik amaçlılık yerine araçlılığı, mitolojiler yerine kurumları, karizma yerine bireyi’ siyasal iktidarın meşruiyet kaynakları olarak ilan etmiştir. Uzun tarihsel evrimden sonra günümüzde siyaset; halkın yönetime etkin katılımı, farklı düşüncelerin özgürce ifadesi, örgütlenmesi ve temsili, düşünce özgürlüğü, çoğunluğun yönetimi ve azınlığın haklarının 
korunması, temel hak ve özgürlüklerin güvence altına alınması ve hukukun üstünlüğü şeklinde özetlenebilecek bir dizi ilkenin çerçevesini oluşturmaktadır (Çetin, 2012: X)”.

Türkiye'de ise siyasal katılım Batılılaşma süreci ile koşut olarak gelişmiştir. İlk önemli adım 1839 Tanzimat Fermanı’yla uyrukların temel haklarının ve yasa önünde eşitliklerinin tanınmasıdır. Bunu 1876 'da I. Meşrutiyet'in ilanı, ertesi yıl da ilk parlamentonun kurulması izlemiştir. Bu deneyim kısa sürmüş, buna karşılık 1908'de ilan edilen II. Meşrutiyet'le, ilk yaygın siyasal katılım gerçekleştirilmiştir. İmparatorluğun yıkılışına dek süren bu kısa dönemde, dört kez genel seçim yapılmış, birçok siyasal parti kurulmuş, ilk sendikalar ve grevler ortaya çıkmış, yaygın bir dernekleşme görülmüş, kadın hakları savunulmaya başlanmış, çeşitli dergi ve gazeteler yayınlanmış, kısacası yönetimden hesap soran, O’na görüş bildiren, O'na katılmayı kendinde hak gören çağdaş yurttaş tipi doğmuştur (Eroğlu, 2012b: 197).

Siyasal katılmanın siyasette çok önemli bir yeri vardır ve sadece oy kullanmak yahut siyasal mitinglere katılmaktan ibaret değildir. Siyasal katılma, "siyasete olan basit ilgi ve meraktan başlayıp siyasal eyleme kadar giden geniş bir tutum ve etkinlik alanını (Tokgöz: 2008: 177)" kapsar. Bu süreçte insanları "ilgi; önemseme; bilgi ve eylem (Kapani, 2009: 144)" gibi motivasyonlar katılmaya sevk edebilirken, "kişisel bağlılık; dayanışma; çıkar ve yurttaşlık duygusu (Anık, 2000: 161 ve Özer, 2004: 88) gibi motivasyon unsurları da insanları siyasanın bir parçası yapar.

En geniş anlamıyla siyasal katılım; kişinin/tarafların, kendilerince veya başkalarınca tasarlanmış, merkezi ya da yöresel devlet organlarının personelini, devletin çeşitli düzeylerdeki karar ve uygulamalarını etkilemek üzere yaptıkları hukuki ve ya hukuk dışı, başarılı veya başarısız eylem ve faaliyetlerin tamamına denir.

\subsubsection{Siyasi Katılım İçin Gerekli Olan Asgari Şartlar}

Siyasal katılmanın bir takım "olmazsa olmaz” koşulları vardır. Devletin varlığı ve bağımsızlığı, yönetilenlerin can güvenliği ve eğitimi, uygun bir tüzel çerçevenin varlığı (seçmeyi ve seçilmeyi, siyasal örgütlenmeyi, eşit koşullarda yönetimde görev almayl, mahkemeler önünde düzgün yargı hakkından yararlanmayı, basın özgülüğünü, barışçı toplantı hakkını, asgari ölçülerde bile olsa yasal bir çerçeveye oturtmuş olmak), katılmayı engellemeyen bir ideolojik bağlam (katılmaya kalkışma 'kendini bilmezlik' ya da 'büyüklere saygısızlık' sayıldı̆̆ından, ya da yalnızca 'değmez' bulunduğundan, ya da herhangi bir düşüngüsel nedenden dolayl, siyasal katılımcllık uygulamada görülmeyebilir), yönetilenleri yönetim işlerinden haberdar eden bir iletişim düzeninin varlığ bu ortamın belli başlı bileşenleridir. Açıktır ki; ortamı belirleyen bu altı boyutun her biri ne kadar gelişmiş olursa, siyasal katılımcılık da o ölçüde güçlenecektir. Siyasal katılma kavramının içinin doldurulması için bakılması gereken ikinci öğe; katılmanın özneleridir. 'Kim katılıyor?' sorusunu yanıtlayabilmek için konuya hukuk ve toplumbilim olmak üzere iki açıdan yaklaşmak gerekir. Hukuk açısından, siyasal hakların temelinde, düşünce özgürlüğünü ve bu özgürlüğün gerçekten yaşama geçirilmesini sağlayan bütün hak ve özgürlüklerin yer aldığı görülür. Toplumbilimsel açıdan ise uygulamada yaş, cinsiyet, sınıfsal konum gibi sosyo-demografik faktörler itibariyle kimlerin, hangi ölçüde siyasal haklardan yararlandığına/yararlanabildiğine bakmak gerekir (Eroğlu, 2012b: 198-201).

Katılmanın somut biçimlerine ve bu biçimleri etkileyen etmenlere bakıldığında, iki genel sınır vardır: Bir kere katılma eylemi gönüllü olmalıdır. Örneğin oy vermenin para cezasına bağlanması, bu ilkeyle çelişir. İkinci genel sınır, katılanların amaçlarına ve kullandıkları yönteme ilişkindir. Amaç düzenin yıkılmasıysa, buna, katılım açısından meşru 
bir etkinlik denilemez. Buna ek olarak, bir davranışın siyasal katılma çerçevesinde görülebilmesi için açıkça hukuk ve düzen dışı olmaması gerekir (Eroğlu, 2012b: 198-202).

Bu noktada literatürde söylem farklılıklarına rastlanmaktadır. Bazı kaynaklarda hukuk ve düzen dışı etkinlikler siyasal katılma olarak görülmezken; bazı kaynaklarda karar mercilerinin dikkatini çekecek her türlü hukuki ve/veya hukuk dışı eylem siyasal katılma olarak nitelendirilmektedir. Örneğin bazı kaynaklar "grev yapmak, trafiği engellemek, boykot, işgal, saldırı ve benzeri eylemler gibi yasal olmayan olağandışı etkinlikleri (Tosun ve Tepeciklioğlu, 2012: 325)" de siyasal katılma şekli olarak ifade edebilmektedir. Bize göre siyasal katılma için hukuk dışı/hukuki ayrımı ol( $a$ )maz. Burada belki -yapıc1, -yıkıcı veya -hukuki, -hukuk dışı şeklinde bir ayrıma gidilebilir. Yani siyaseten karar merciinin dikkatini çekecek, kamuoyu yaratacak her türlü eylem siyasal katılma olarak nitelendirilmeli; ancak yapıcı/yıkıcı veya hukuki/hukuk dışı gibi bir tasnife tabi tutulmalıdır. Son olarak "katılma tanımı gereği aktif bir davranışı nitelediğinden, düşün aşamasında kamlı veya eyleme dönüşmemiş tutum ve görüşlerin siyasal katılma kapsamına alınamayacağını düşünmekteyiz (Tosun ve Tepeciklioğlu, 2012: 325)”’.

\subsubsection{Siyasal Katılım Düzeyleri ve Çeşitleri}

Katılma düzeyleri toplumdan topluma, rejimden rejime değişiklik gösterebildiği gibi, toplum üyeleri politikaya aynı düzeyde alaka da duymayabilir. Literatürde siyasal katılmanın düzeyleri ve yoğunluğu ile ilgili farkı kategorilere rastlanmaktadır: Bunlardan birinde Robert Dahl, insanların siyasete şu dört şekilde ilgi duyulduğunu ifade etmiştir: Siyasal olmayan tabaka; Siyasal tabaka; Iktidar peşinde koşanlar ve İktidar sahipleri. Benzer şekilde, Baykal ise toplumda siyasete üç farklı düzeyde ilgi duyduğunu iddia etmiştir. Bunlar: a) Siyasal olayları izleme; b) Siyasal olaylar hakkında tavır takınma; c) Siyasal olayların içine karışma: şeklindedir (akt. Özer, 2004: 86-87).

Bir diğer sınıflamada Verba ve Nie (akt. Özer: 2004: 85-86), bireylerin siyasal yaşama altı düzeyde katılabileceklerini öne sürmüştür. Bunlar: a) Siyasal sürece hiç katılmayanlar: b) Oy kullananlar: c) Kişisel sorunlarıyla sınırlı katılımcılar: d) Topluluk düzeyinde katılımcılar (bireysel çıkarlarının ötesinde yaşadıkları çevre ile ya da içinde yer aldıkları toplulukların sorunlarının çözümü için siyasal iktidarı, belediye ve siyasal yönetimi etkilemeye çalışanlar) e) Kampanyacılar: Seçim Kampanyalarında aktif olarak görev alanlar) $f$ ) Son olarak da siyasal partilerde görev almanın yanı sıra siyasal seçimlere faal olarak katılanlardır.

M.E. Olsen ise, toplumda siyasi katılımı altı tabaka halinde kategorize etmiştir (Taşdelen, 2011: 166-167): (a) Liderler: Resmi yönetim yapısında yer/görev alan seçilmiş veya atanmış kimseler). (b) Siyasi aktivistler: Siyasi partilerin ve diğer siyasi örgütlerin faal üyeleri. (c): Siyasi iletişiciler: Siyasi haberleri, değerleri, normları, inançları edinir veya naklederler. (d) Siyasi vatandaşlar: Bir vatandaşın beklenilen mesuliyetlerini icra eden ancak siyasette yer almayan kimseler. (e) Siyasi marjinaller: Siyasi sistemle çok az temas halinde olanlar. (f) Siyasi dışlanmışlar: Siyasete hiçbir surette katılımda bulunmayanlar. Bunlara "apatetik yahut parokial (hareketsiz vatandaşlar) da denir (Aybek, 2008: 63)".

Katılma biçimleri eylemin yoğunluk ve zorluk derecesine göre de sınıflandırılabilmektedir. Oy kullanmak, tartışmalara girmek, başkalarını belirli bir yönde oy kullanmaya ikna etmek, rozet takmak gibi eylemler gözlemci eylemler olarak nitelendirilirken, siyasal bir liderle ilişki kurmak, bir partiye parasal yardımda bulunmak, üye olmak, mitinglere katılmak aracı eylemler olarak adlandırılır. Daha yoğun siyasal katılıma yönelik olan, seçim kampanyalarında çalışmak, parti içi toplantılara katılmak, parti 
için bağış toplamaya çalışmak, aday olmak gibi eylemler ise siyasal mücadeleye yönelik eylemler olarak sınıflandırılmaktadır (Tosun ve Tepeciklioğlu, 2012: 325). Yine faaliyetin türüne göre farklı sınıflandırmaya göre de siyasal katılma biçimleri gladyatör, seyirci ve geçiş faaliyetleri olarak üç grupta incelenebilir: Gladyatör Faaliyetleri: Bir toplantı veya mitinge katılma, bir parti veya aday için para yardımı yapma, bir siyasal liderle temas kurmadır. Seyirci Faaliyetleri: Bir partinin rozetini taşıma, bir kişinin siyasal tercihini etkilemeye çalışmak, bir siyasal tartışmaya katılmak, oy vermek. Geçiş Faaliyetleri ise, siyasal katılım açısından faaliyete katılmama, toplumda siyasal olmayan bir tabakayı oluşturma, siyasal olaylarla ilgilenmemedir (Üste, 2011: 106). Daha sonra bu siniflamaya teamül dış1 katılım türüne örnek teşkil eden protestocular dâhil edilmiştir (Taşdelen, 2011: 166).

Diğer taraftan katılma biçimleri çeşitli özelliklerine bakılarak nitelendirilebilir. Bir kere katılma (a) bireysel olabilir (örneğin aday olma), (b) toplu olabilir (örneğin bir gösteri yürüyüşüne katılma), (c) örgütlü olabilir (örneğin siyasal partilerin çalışmaları) (Eroğlu, 2012b: 203).

Başka bir açıdan açık veya gizli olabilir. Herkesin önünde yapılan faaliyetler açık katılımı oluştururken, kendi dar çevresi içerisinde (aile, arkadaş) de gizli bir şekilde gerçekleşebilir. İkinci olarak siyasi katılım bağımsız "özerk" yani ferdin kendi isteği ile gerçekleşebileceği gibi, itaatkâr "mobilize" yani istenilen davranışlarda bulunma şeklinde de gerçekleşebilir. Özerk katılma devlet organlarınca alınacak kararları etkilemek üzere aktörün kendisi tarafından tasarlanmış faaliyetlerdir. Mobilize katılma ise devlet organlarınca alınacak kararları etkilemek üzere aktörün kendisi dışındaki bir kişi tarafından tasarlanmış faaliyetlerdir (Kahraman, 2011: 50).

\begin{tabular}{|c|c|c|c|}
\hline \multicolumn{4}{|c|}{ Siyasal katılım biçimleri aktif ve pasif katılım olmak üzere iki başlık altında toplanabilir: } \\
\hline & & $\begin{array}{c}\text { Bireylerin Siyasal Sisteme } \\
\text { Verdikleri }\end{array}$ & $\begin{array}{c}\text { Bireylerin Siyasal Sistemden } \\
\text { Aldıkları }\end{array}$ \\
\hline \multirow{2}{*}{$\begin{array}{l}\text { Aktif } \\
\text { Katılma }\end{array}$} & Aletsel & $\begin{array}{l}\text { Lider seçimi (oylama), Parti içi } \\
\text { faaliyetleri, Para yardımında } \\
\text { bulunma, Gönüllü ise koşma, } \\
\text { İtaatsizlik }\end{array}$ & $\begin{array}{l}\text { Mevki sağlama, Haberleşme } \\
\text { imkanları, Hizmetler, Menfaatler, } \\
\text { Menfaat çatışmasının çözümü, } \\
\text { Adalet }\end{array}$ \\
\hline & Açıklayıcı & $\begin{array}{l}\text { Sadakat (bağlllık) bildirisi, } \\
\text { Gösteri, Protesto (oy ile), Siyasal } \\
\text { tartısma, İkna etme }\end{array}$ & \\
\hline \multicolumn{2}{|c|}{ Pasif Katılma } & $\begin{array}{l}\text { Itaat, Riza (muvafakat), Askere } \\
\text { gitme, Vergi ödeme, Kayltsızlık }\end{array}$ & \\
\hline
\end{tabular}

\subsubsection{Siyasal Katılımı Etkileyen Faktörler}

Siyasal katılma sosyo-demografik, kültürel, psikolojik, ekonomik, hukuki v.d. farklı alanların çapraz etkisi ile girift bir birçok faktörün ürünü olarak ortaya çıkan, çok boyutlu tutum ve davranışlardır.

Siyasal katılmayı etkileyen etkenlerle ilgili değişik birçok sınıflandırmaya rastlanmaktadır. Bunlardan bazılarına göre bu etkenler sosyo-ekonomik etkenler, psikolojik etkenler ve siyasal etkenler olmak üzere üçe ayrılır. Sosyo-ekonomik etkenler gelir durumu, meslek, yaş, cinsiyet, yerleşim yeri ve bunun gibi sosyo-ekonomik faktörlerdir. Psikolojik 
etkenler; bireyin olgunluğu, etkinliği ve girişkenliği açısından genelde siyasal katılım üzerinde olumlu etki yaparken; çekingenlik ve yabancılaşma ise katılmayı olumsuz etkileyen faktörlerdir. Diğer etmenler; tüm bu etmenlerin yanında siyasete katılma bir takım hukuksal ve siyasal etkenlere de tabidir. Bu kriterleri sağlamayan kişiler siyasal hayata da katılmazlar. Aynı zamanda demokrasilerde ve otoriter rejimlerde de siyasal katılma büyük farklılıklar göstermektedir. Özellikle otoriter rejimlerde siyasal katılma daha çok zorluklarla ve baskı altında yapılan bir eylem olup, hür bir insanın siyasal hayata katılması ile arasında büyük farklılıklar bulunmaktadır (Tosun ve Tepeciklioğlu, 2012: 326328).

Farklı bir sınıflandırmaya göre de iki güçlü akımdan söz edilebilir: Birey düzeyinde açıklamalar ile politik-kurumsal açıklamalar. Bireyleri eğitim, gelir, cinsiyet ve din gibi sosyodemografik açıdan ele alan yaklaşımlar birey düzeyinde açıklamaların bileşenleridir. Politik ve kurumsal açıklamalar ise, bir yandan partilerin ve politik örgütlerin harekete geçirici aktivitelerinin rolüne vurgu yaparken, diğer yandan seçmen kayıt şartları, seçimlerin zamanlaması ve parti sistemi doğrultusunda seçmenlere anlamlı tercihler sunması gibi kurumsal sinırlara da vurgu yapar (Manza, Brooks ve Sauder, 2010: 221). Tüm bu faktörlerin yanında seçmenin rasyonel bir varlık olduğu gerçeğinden hareket eden yaklaşımlar da vardır. Anthony Downs'ın 1957 tarihli 'Rasyonel-Tercih Teorisi'ne katkıda bulunan 'Demokrasinin İktisadi Teorisi' adlı kitabı insanların eğer 'kazançlar maliyetleri aşıyorsa' oy kullandığını teorize etmiştir. Yani eğer kazanılacak şeyler maliyetlerden daha ağır gelirse vatandaşlar oy verme zahmetine katlanır. Siyasal enformasyonun hem kişisel hem de finansal maliyeti de bir kişinin oy kullanıp kullanmayacağını belirler (Roskin v.d., 2013: 247).

Siyasal katılmayı etkileyen etmenler arasında sosyodemografik faktörlerin rolü ve önemi ise artık yadsınmamaktadır. Yapılan araştırmalara göre herkes, siyasal haberleri takip edecek veya siyasal toplantılara katılacak ilgi ve enerjiye sahip değildir. Dolayısıyla çoğu toplumlarda fakirlerin ve eğitimsizlerin oy kullanması daha zayıf bir ihtimaldir (Roskin v.d., 2013: 247). Bununla birlikte, siyasi katılım eğilimi nispeten daha yüksek grupların genelde erkekler, orta yaşlılar, siyasi ilgi düzeyi yüksek ailelerin çocukları, serbest meslek mensupları, yüksek gelirliler ve şehirde ikamet edenler oldukları şeklinde yaygın bir kanaat olmakla birlikte bu her zaman geçerli de değildir (Taşdelen, 2011: 168). Ancak genel kabullere göre, bir kere, kadınların ve gençlerin katılma olanakları, yetişkin erkeklerinkine göre çok daha kısıtlıdır. Siyasal katılmada eğitim, etkisi doğrudan doğruya görülen temel bir öğedir. Kimi meslekler de siyasal katılma açısından üstün konumdadır. Birçok yerde, katılma etkinliğinin en ön sıralarında hukukçuların yer aldığı görülür. Toplu iletişim araçlarının başköşelerini tutmuş kişiler de, birçok yerde çok etkilidirler. Konuya sınıf açısından bakıldığında işçilerin ya da genellikle emekçilerin, siyasal katılmada görece etkisiz kaldıkları, buna karşılık, sözcülüklerini yapan baskı kümeleri aracılığıyla ya da doğrudan kimi üyelerinin girişimiyle, egemen sınıfların çok etkili oldukları görülür (Eroğlu, 2012b: 201).

\subsection{Kamuoyu ve Miting}

Kamuoyunun oluşumu, yapısı ve niteliği ile onun içinde oluştuğu siyasal sistem ve siyasal ortam arasında yakın bir ilişski olduğu bilinen bir gerçektir. Siyasa ve toplumbilimciler, genellikle, demokratik rejimlerde serbestçe oluşan kamuoyu ile demokratik olmayan, otoriter ve totaliter rejimlerde oluşturulan (yaratılan) kamuoyu arasında bir ayrım yapma eğilimindedirler (Emiroğlu, 2006: 594-595). Özellikle demokrasilerde kamuoyu son derece önemsenir. Hatta bir demokrasinin gelişmişlik düzeyi, 
o toplumda tartışmalı bir sorun hakkında var olan kamuoyunun özgürlüğü, çeşitliliği ve işleyişiyle doğrudan alakalıdır. Demokrasinin tek meşruiyet kaynağı ise toplumsal rızadır. Toplumsal rıza bir toplum içinde farklı siyasal ve ekonomik taleplerin ve çıkar birlikteliklerinin (partiler, sivil toplum örgütleri) olduğu gerçeği üzerine kurulu uzlaşma ve konsensüs derecesidir (Çetin, 2012: XII). Burada kamuoyu ile bireysel kanaatleri birbirine karıştırmamak gerekir. "Bir kadının komşusunun diniyle ilgili kanaati kamuoyunun parçası olmaz. Fakat devlet okullarında dua edilmesiyle ilgili kanaati kamuoyunun parçası olur. Kamuoyu özel meselelere değil sosyal ve politik meselelere işaret eder. Anektedotlara dayalı kanıt, bu anekdotun temsil edici olup olmadığını bilmenin hiçbir yolu olmadığından, kamuoyunun zayıf bir göstergesidir (Roskin v.d., 2013: 164)”.

Kavram olarak kamuoyu, halkın düşüncesi veya kanaati anlamına gelir. Kelime doğrudan "halkın bir konuda verdiği hüküm veya tercih" çağrışımı yapsa da, aslında birden fazla fikri barındırır. Kamu kelimesi halk veya toplum demektir. Kamuoyu geniş anlamda halkı ilgilendiren belli bir konuda belli bir zamandaki genel yargıyı yahut ortak kanaatleri ifade eder. Dar anlamda ise halkı ilgilendiren veya etkileyen konularda bireyin sahip olduğu görüş ve kanaatlerin toplamıdır. Herkesin üzerinde anlaştığ 1 bir fikre varmak çok zordur, hatta imkânsızdır. Bu bakımdan kamuoyu hâkim kanaattir ve içinde değişik fikirleri, karşıt görüşleri, kararsız ve hatta ilgisiz insanların eğilimlerini barındırır (Türköne, 2012: 310). Çeşitli çalışmalarda, belirli konularda kamuoyuyla hükümet politikaları arasında eşleşme olduğu tespit edilmiştir (Weakliem, 2010: 254-255). Yani kamuoyunun hükümet politikalarını etkilediği/şekillendirdiği bulgulanmıştır. Ancak burada dikkat edilmesi gereken husus; kamuoyunun çoğunluğun kanısını yansıtabileceği gibi bazı durumlarda yansıtmayabileceği gerçeğidir. Zira "azınlığın kararlı bir şekilde benimsediği bir görüş, çoğunluğun gevşek olarak benimsediği bir görüşe ağır basabilir (Kışlal1, 2010: 201)”.

$\mathrm{Bu}$ bağlamda siyasal katılımın en etkili enstrümanlarından biri olan ve çalışmanın özünü oluşturan miting ise, 'gösteri amacıyla veya bir olaya dikkati çekmek için genellikle açık alanlarda yapılan (tdk.gov.tr)', 'silahsız, saldırısız, teşkilatlı toplantılardır. Mitingler için genellikle açık yerler ve meydanlar kullanılır. Çünkü herhangi bir konunun ve düşüncenin izah edilerek toplantıdakilere kabul ettirilmesinden çok; belli bir insan grubu topluluğunun, belli konu ve olaylardaki düşünce ve tutumunu, siyasi iktidara, çevre halkına, kamuoyuna duyurma ve onları etkileme gayesi güder (http://www.turkcebilgi.com/miting\#bilgi)' ve böylece bir kamuoyu yaratmak ister.

Anayasanın 34. Maddesi'ne göre "herkes, önceden izin almadan, silahsız ve saldırısız toplantı ve gösteri yürüyüşü düzenleme hakkına sahiptir. Toplantı ve gösteri yürüyüşü hakkı ancak, millî güvenlik, kamu düzeni, suç işlenmesinin önlenmesi, genel sağlığın ve genel ahlâkın veya başkalarının hak ve özgürlüklerinin korunması amacıyla ve kanunla sınırlanabilir". Anayasanın 34 Maddesi'ni düzenleyen 2911 Sayılı Toplantı ve Gösteri Yürüyüşleri Kanunu'nun 2 maddesine göre; a) Toplantı: Belirli konular üzerinde halk1 aydınlatmak ve bir kamuoyu yaratmak suretiyle o konuyu benimsetmek için gerçek ve tüzelkişiler tarafından bu Kanun çerçevesinde düzenlenen açık ve kapalı yer toplantıları; b) Gösteri yürüyüşü: Belirli konular üzerinde halkı aydınlatmak ve bir kamuoyu yaratmak suretiyle o konuyu benimsetmek için gerçek ve tüzel kişiler tarafindan bu Kanun çerçevesinde düzenlenen yürüyüşleridir (mevzuat.gov.tr). $\mathrm{Bu}$ tanımlara göre miting meydanlarındaki seçmenlerin 'kitle' olduğunu söyleyebiliriz. Kalabalık, yığın anlamındaki kitle kelimesi basit ve sıradan anlamıyla ırkları, meslekleri ve kendilerini bir araya toplayan tesadüf ne olursa olsun rastgele bir bireyler topluluğunu ifade eder. Öte yandan kitlelerde 
bilinçli kişilik ortadan silinir, bütün bu birleşmiş fertlerin düşünceleri ve duyguları tek bir tarafa yönelir (Le Bon, 1997: 19-20).

Kitlelerin hususi özelliklerinin/karakterlerinin oluşmasının ise çeşitli sebepler vardır: Birinci Sebep; kitle içinde bulunan birey sadece çokluğun, sayı fazlalığının verdiği bir duygu ile tek başına olduğu vakit frenleyebileceği içgüdülerine kendisini teslim ederek yenilmez bir güç kazanır. Kitleler isimsiz ve dolayısıyla mesuliyetsiz oldukları için fertleri daima, her yerde kuşatıcı rol oynayan kendi sorunluluk duygularından bütünüyle uzaklaşırlar ve onları içgüdülerine daha kolayca bırakırlar. İkinci Sebep; bir toplulukta her duygu sirayet edici olduğu gerçeğidir. O derece sirayet edicidir ki, birey, kişisel çıkarını topluluğun çıkarına kolayca feda eder. Üçüncü Sebep; kitle psikolojisi kitle içinde bireylerde, yalnız yaşayan bireylerin karakterlerine oranla zıt karakterler meydana getirir (Le Bon, 1997: 26-27).

\section{ALAN ARASTIRMASI}

\subsection{Araştırmanın Amacı ve Önemi}

Çalışmanın asıl amacı; [siyasi] mitinglerin sosyopolitik analizini yaparak literatüre belli bir katkı sunmak ve ilgilisi için seçmenin daha yakından tanınmasını sağlamaktır.

Çalışmanın alt amaçları ise şunlardır:

Mitinge katılanların politik sosyo-demografisini ortaya koymak,

Mitingin siyasal iletişim kanallarını tespit etmek,

Seçmenlerin mitinge katılım nedenleri ve alışkanlığını (sıklığını) belirlemek,

Mitinglerin seçmenin karar ve tercihlerini etkileme gücünü anlamak,

Mitinge katılanların 'ne kadarının seyirci, ne kadarının taraftar' olduğunu bulgulamak ve analiz etmek,

Miting alanındaki seçmenin ruh haline ilişkin psiko-politik bir tahlil yapmak,

Döneminde biri iktidar, diğeri muhalefet olan meclisteki iki sağ parti seçmeninin politik sosyo-demografisini, mitinge katılım nedenlerini, mitingden etkilenme düzeylerini ve oluşan kolektif ruh halleri gibi değişkenleri karşılaştırarak yorumlamaktır.

\subsection{Araştırmanın Metodolojisi}

$\mathrm{Bu}$ çalışma, miting(ler) üzerine yapılan ampirik bir çalışmadır. Anket tekniğinin kullanıldığı çalışmada, 29 Mart 2009 Yerel Seçimleri öncesinde Ak Parti ve MHP'nin Elazığ ilinde yaptıkları mitingler örneklem seçilmiştir. Örneklem belirlenirken siyasal yelpazede farklı uçlarda yer alan partileri araştırarak marjinal eğilimleri bulgulamak yerine; merkez siyasetinden iki sağ parti seçmeninin sosyopolitik analizini yapmak yoluna gidilmiştir. Böylece siyasi mitinglerin gerçek analizinin yapılabileceği düşünülmüştür. Miting alanında tek tek yapılan ve yanıtları anında alınan anket, rastgele seçilmiş 18 yaş ve üstü 300 seçmene uygulanmıştır. Katılımcıların kimlik bilgilerinin alınmadığı araştırma verileri, SPSS 18.0 paket programı kullanılarak analiz edilmiştir. 


\subsection{Bulgular ve Verilerin Analizi}

\subsubsection{Katılımcıların Sosyo-Demografik Profili}

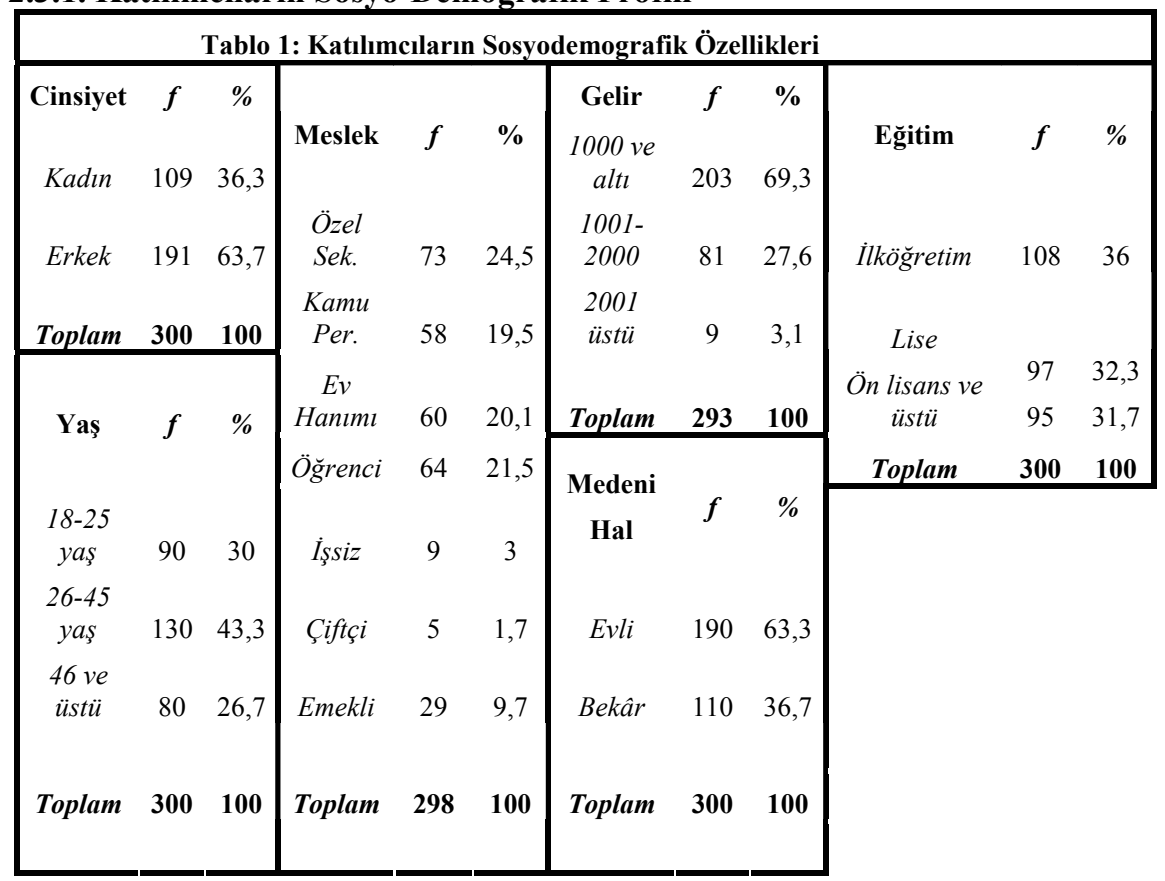

\subsubsection{Mitinge İlden ve İl Dışından Katılım Oranı}

Tablo 2: Mitinge Katılmak İçin Nereden Geldiniz?

$$
\begin{gathered}
\text { Şehir Merkezi } \\
\text { İlçe } \\
\text { Elazı̆̆ dışı } \\
\text { Toplam }
\end{gathered}
$$$$
\text { f } \%
$$$$
248
$$$$
82,7
$$

113,7

300

100

Mitingdekilerin 82,7'si il merkezinden; \%13,7'si ilçelerden, \%3,7'si de il dışından gelmiştir.

\section{Sosyodemografik Faktörler İle İl ve İ Dışından Katılım Oranı Arasındaki İlişki}

Cinsiyet ile katılımcıların mitinge katılmak için geldiği yer arasında anlamlı bir farklılık vardır. Kadınların \%89,9'u, erkeklerin \%78,5'i il merkezinden; erkeklerin \%21,5'i, kadınların \%10,1'i ise ilçelerinden ve il dışından katılmaktadır. İl merkeziden gelen kadın oranı erkeklerden; ilçe ve il dışından gelen erkek oranı da kadınlardan fazladır. Yaş açısından ise yaş arttıkça mitinge şehir dışından gelip katılanların oranı düşmüştür. Böylece gençlerin şehir dışındaki mitinglere gitme eğiliminin, ileri yaştakilere göre daha fazla olduğu söylenebilir. 


\subsubsection{Alandaki Seçmenlerin Mitinglere Katılma Sıklığı}

$\begin{array}{ccc}\text { Tablo 3: Mitinglere hangi sıklıkla katılırsınız? } & \boldsymbol{f} & \boldsymbol{\%} \\ \text { İlk kez katılıyorum } & \mathbf{7 5} & 25,1 \\ \text { Nadiren } & \mathbf{7 8} & 26,1 \\ \text { Ara sıra } & \mathbf{5 3} & 17,7 \\ \text { Siklıkla } & \mathbf{6 3} & 21,1 \\ \text { Her zaman } & \mathbf{3 0} & 10,0 \\ \text { Toplam } & \mathbf{2 9 9} & \mathbf{1 0 0}\end{array}$

Katılımcıların \%25,1'i ilk kez, \%26,1'i nadiren, \%17,7'si ara sıra, \%21,1'i s1klıkla bir mitinge katıldığını söylerken; \%10’u her zaman mitinglere katıldığını belirtmiştir.

\section{Illişki \\ Sosyodemografik Faktörler İle Mitinge Katılma Sıklı̆̆ı (Alışkanlı̆̆ı) Arasındaki}

Cinsiyet ile miting(ler)e katılma sıklığı arasında anlamlı bir farklılık olup erkekler kadınlardan daha fazla ve daha sık mitinglere katılmaktadır. Yaş düştükçe mitinge hiç katılmadığını söyleyenlerin oranı artmış; her zaman katılırım diyenlerin oranı düşmüştür. Ayrıca 18-45 yaşındaki gençlerde ve orta yaşlılarda mitinglere katılım sıklığı 46 yaş ve üstündekilere göre daha düşüktür. $\mathrm{Bu}$ bağlamda ileri yaştakilerde mitinglere katılma sıklığının genç yaştakilere göre daha fazla olduğu söylenebilir. Meslek grupları içinde hiç katılmayanlar arasında çoğunluğu ev hanımları $(\% 51,7)$, nadiren katılanlar arasında öğrenciler $(\% 40,6)$, ara sıra katılanlar arasında özel sektör çalışanları $(\% 27,4)$, sıklıkla katılanlar arasında emekliler $(\% 48,3)$ oluştururken, her zaman katılanlar arasında çoğunluğu ise kamu çalışanları $(\% 22,8)$ oluşturmaktadır. Eğitim düzeyi arttıkça mitinglere "ilk kez katılıyorum" diyenlerin oranı düşerken; eğitim seviyesi arttıkça "her zaman katılırım" diyenlerin oranı artmıştır. Mitinglere katılım düzeyi ile eğitim arasında anlamlı bir farklılık olup, eğitim düzeyi yüksek olanların mitinge katılım düzeyi daha yüksektir.

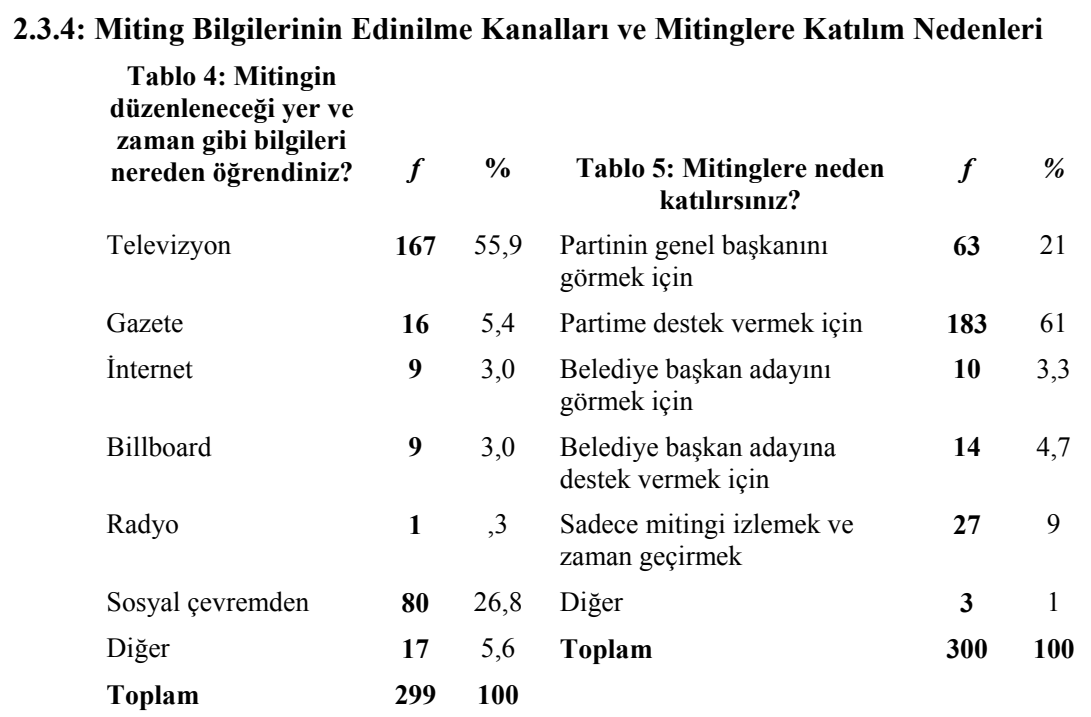


Katılımcılardan \%55,9'u mitingin düzenleneceği zamanı ve yeri televizyondan, $\% 26,8$ 'i arkadaşlarından ve sosyal çevresinden, \%5,4'ü gazetelerden, \%3'ü internetten, \%3'ü billboardlardan, \%0,3'ü radyodan öğrenirken, \%5,6's1 de diğer araç ve aracilardan öğrenmiştir. Katılımcılardan \%61'i mitingine geldiği partiye destek vermek, \%21'i partinin genel başkanını görmek, \%9'u mitingi izlemek ve merak gidermek, \%4,7'si belediye başkan adayına destek vermek, \%3,3'ü belediye başkan adayın görmek, \%1'i de diğer sebeplerle mitinge geldiğini ifade etmiştir. Katılımcıların, daha çok, partisine destek vermek, partinin genel başkanını görmek ve mitingi izlemek için katıldığı anlaşılmaktadır.

\section{Sosyodemografik Faktörler İle Mitinge Katılım Nedeni Arasındaki İlişki}

Kadınların \%64,2'si, erkeklerin ise \%59,2'si mitingine geldiği partiye destek vermek; kadınların \%22,9'u, erkeklerin ise \%19,9'u mitingine geldiği partinin genel başkanını görmek; kadınların \%4,6'sı, erkeklerin ise \%2,6'sı belediye başkan adayını görmek için mitinge katılırken; erkeklerin ise \%11,5'i, kadınların \%4,6's1 mitingi izlemek; erkeklerin \%5,2'si kadınların \%3,7'si belediye başkan adayına destek vermek için mitinge geldiklerini ifade etmiştir. Partinin genel başkanını görmek, partiye destek vermek, belediye başkan adayını görmek için gelen kadın oranı erkeklerden daha fazladır. Diğer taraftan belediye başkan adayına destek vermek, mitingi izlemek için gelen erkeklerin oranı ise kadınlardan daha fazladır. Yaş açısından, yaş arttıkça partinin genel başkanını görmek için geldiğini söyleyenlerin oranı düşmüş; belediye başkan adayına destek olmak için gelenlerin oranı artmıştır . Eğitim seviyesi bakımından mitingine geldiği partiye destek vermek ve belediye başkan adayını görmek için gelenler arasında çoğunluğu ilköğretim mezunları; partinin genel başkanını görmek ve belediye başkanına destek vermek için gelenler arasında çoğunluğu lise mezunları ve mitingi izlemek için gelenler arasında çoğunluğu ise ön lisans ve üstü eğitim düzeyindekiler oluşturmaktadır. Mesleki açıdan ise, işsizlerden 'belediye başkan adayını görmek' ve 'mitingi izlemek'; çiftçilerden 'belediye başkan adayına destek vermek' için mitinge geldiğini söyleyen hiçbir katılımcıya rastlanmamıştır. Meslekler arasında en çok ev hanımları mitingine geldiği partiye destek vermek $(\% 71,7)$; öğrenciler partinin genel başkanını görmek (\%25), çiftçiler mitingi izlemek (\%20); işsizler belediye başkan adayına destek vermek (\%22,2); çiftçiler ise belediye başkan adayını görmek için (\%20) daha çok mitinge gitmiştir.

\subsection{5: Seçmenlerin Oy Vermeyi Düşündüğü ve Kazanacağını Öngördüğü Parti}

\section{Tablo 6: Hangi partiye} oy vereceksiniz?

Mitinginde bulunduğum partiye

Farklı bir parti

Kararsizım

Toplam

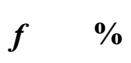

242

37

17

296
Tablo 7: Sizce (önümüzdeki) seçimleri hangi parti kazanacak?

Şu anda mitinginde olduğum parti

Katılımcılardan \%81,8'i mitinginde olduğu partiye, \%12,5'i mitinginde olduğu partiden farklı bir partiye oy vereceğini söylerken \%5,7'si de kararsız olduğunu belirtmiştir. Başka bir açıdan katılımcıların \%82,6'sı mitinginde olduğu partinin, \%11,1'i mitinginde olduğu partiden farklı bir partinin kazanacağını tahmin ederken; \%6,3’ü de fikri olmadığını ifade etmiştir. 


\subsection{6: Mitinglerin Karar ve Tercihleri Etkileme Biçimi}

$\begin{array}{ccc}\begin{array}{c}\text { Tablo 8: Miting tercih ve } \\ \text { kararmız hangi yönde etkilemektedir? }\end{array} & \boldsymbol{f} & \mathbf{\%} \\ \text { Olumlu } & \mathbf{1 5 3} & 51,9 \\ \text { Olumsuz } & \mathbf{1 1} & 3,7 \\ \text { Etkisi olmadı } & \mathbf{1 3 1} & 44,4 \\ \text { Toplam } & \mathbf{2 9 5} & \mathbf{1 0 0}\end{array}$

Katılımcılardan \%51,9'u katılmış olduğu mitingin oy verme davranışını olumlu etkilediğini, \%44,4'ü olumlu veya olumsuz bir etkisi olmadığını, \%3,7'si de olumsuz etkilediğini söylemiştir.

\section{Sosyodemografik Faktörler İle Mitinglerin Seçmen Kararını Etkileme Biçimi Arasındaki İlişki}

Anlamlı denilecek bir düzeyde olmamakla birlikte; mitingin kararlarını olumsuz yönde etkilediğini söyleyen erkek oranı kadınlardan daha fazladır. Gelir olarak $1000 \mathrm{TL}$ ve altında geliri olanların \%4'ü, 1001-2000 TL arası geliri olanların \%2,6'sı ve $2001 \mathrm{TL}$ ve üstü geliri olanların \%0'ı mitingin oy verme kararlarını olumsuz etkilediğini söylemiştir. Bu verilere göre gelir düzeyi düştükçe mitinglerden olumsuz etkilenenlerin oranı da artmıştır.

\section{İlişki \\ Mitinge Katılım Sıklı̆̆ İle Mitinglerin Seçmen Kararını Etkileme Biçimi Arasındaki}

Mitinge ilk kez katılanların \%44'ü, nadiren katılanların \%51,4'ü, ara sıra katılanların $\% 50,9$ 'u, sıklıkla katılanların \%54'ü, her zaman katılanların \%70'i mitingin oy verme kararlarını olumlu yönde etkilediğini ifade etmiştir. Bunun yanı sıra miting ilk kez katılanların ve nadiren katılanların \%2,7'sini, ara sira katılanların \%3,8'ini, sıklıkla katılanların \%7,9'unu olumsuz yönde etkilemiştir. Diğer taraftan, her zaman katılanların $\% 30$ 'u, sıklıkla katılanların $\% 38,1$ 'i, ara sıra katılanların $\% 45,3$ 'ü, nadiren katılanların $\% 45,9$ 'u ve ilk defa katılanların $\% 53,3$ 'ü mitingin oy tercihleri üzerinde herhangi bir etkisi olmadığı söylemiştir. Söz konusu verilere göre seçmenlerin mitinglere katılım sıklığ 1 arttıkça [olumlu ve/veya olumsuz yönde] tercihlerinin değiştiğini söyleyenlerin oranı artmış; mitingin siyasal karar ve tercihleri üzerinde bir tesiri olmadığını ifade edenlerin oranı azalmıştır.

\subsection{7: Miting Katılımcılarının Partilere Göre Dağılımı}

$\begin{array}{ccc}\begin{array}{c}\text { Tablo 9: Mitingi Yapılan } \\ \text { Partinin adı }\end{array} & \boldsymbol{f} & \% \\ \text { Ak Parti Mitingi } & \mathbf{1 5 5} & 51,7 \\ \text { Milliyetçi Hareket Partisi Mitingi } & \mathbf{1 4 5} & 48,3 \\ \text { Toplam } & \mathbf{3 0 0} & \mathbf{1 0 0}\end{array}$

Toplam 300 kişinin $155^{\prime} \mathrm{i}(\% 51,7)$ Ak Parti mitingine, 145 'i (\%48,3) de MHP mitingine katılanlardan oluşmaktadır. Ak Parti mitingine gelenlerin \%36,8'i kadın, \%63,2'si erkek; MHP mitingine katılanların 35,9'u kadın, \%64,1'i erkektir. Bu verilere göre her iki partiye gelen kadın-erkek oranları birbirine yakındır. Ak Parti mitingine katılanların \%23,2'si ev hanımı, \%21,9'u özel sektör çalışanı, \%21,3'ü öğrenci, \%20,1'i kamu personeli, \%9,7'si emekli, \%1,9'u işsiz ve \%1,9'u da çiftçidir. MHP mitingine katılanların ise \%27,3'ü özel sektör çalışanı, \%21,7'si öğrenci, \%18,9'u kamu personeli, $\% 16,8$ 'i ev hanımı, $\% 9,8$ 'i emekli, $\% 4,2$ 'si işsiz ve $\% 1,3$ 'ü de çiftçidir. Ak Parti mitingine 
ev hanımı, özel sektör çalışanı ve öğrenci; MHP mitingine kamu personeli, özel sektör çalışanı ve öğrenci daha çok katılmıştır. Ak Parti mitingine katılanların \%43,3'ü ilköğretim, $\% 29$ 'u ön lisans ve üstü, \%27,7'si de lise mezunudur. MHP mitingine katılanların ise \%37,2'si lise, \%34,5'i ön lisans ve üstü, \%28,3'ü de ilköğretim mezundur. Buna göre MHP mitingindekilerin eğitim düzeyinin Ak Parti mitingindekilere göre daha yüksek olduğu söylenebilir.

\section{Seçmenlerin Katıldı̆̆ı Miting ile Oy Vereceği Parti Arasındaki İlişki}

MHP mitinginde 'mitinginde olduğu partiye oy vereceğini' söyleyenlerin oranı; Ak Parti mitinginde ise 'farklı bir partiye oy vereceklerini' söyleyenlerin ve kararsızların oranı daha fazladır (Bkz. Tablo 10).

\section{Seçmenlerin Katıldı̆̆ Miting ile Katılım Nedeni Arasındaki İlişki}

Ak Parti mitingine gelenlerin \%32,3'ü, MHP mitingine gelenlerin \%9'u genel başkanı görmek; Ak Parti mitingine gelenlerin \%4,5'i, MHP mitingine gelenlerin \%2,1'i belediye başkan adayını görmek ve Ak Parti mitingine gelenlerin \%13,5'i MHP mitingine gelenlerin 54,1'i mitingi izlemek için gelmiştir. Bunun yanı sıra MHP mitingine gelenlerin \%79,3'ü, Ak Parti mitingine gelenlerin \%43,9'u partisine destek vermek; MHP mitingine gelenlerin $\% 5,5$ 'i, Ak parti mitingine gelenlerin \%3,9'u belediye başkan adayına destek vermek için mitinge gelmiştir. Buna göre Ak Parti mitinginde genel başkanı, belediye başkan adayını görmek ve mitingi izlemek için gelenlerin oranı daha fazla iken; MHP mitinginde partisine ve başkan adayına destek vermek için gelenlerin oranı daha fazladır. Bu bakımdan parti ile mitinge katılım amacı arasında anlamlı bir farklılık vardır (Bkz. Tablo 11).

\section{Seçmenlerin Katıldı̆̆ı Miting ile Mitinglere Katılım Sıklı̆̆ı Arasındaki İlişki}

MHP mitingine gelenlerden \%28,3'ü, Ak Parti mitingine katılanlardan \%22,1'i ilk kez mitinge katıldığını ifade ederken; Ak Parti mitingine katılanlardan \%77,9'u, MHP mitingine katılanlardan \%71,7'si birden fazla kez mitinge katılmıştır. Buna göre Ak Parti mitingine katılanlardan birden fazla kere mitinge katılanların oranı, MHP mitingine katılanlardan daha fazladır. Başka bir ifadeyle, Ak Parti mitingine katılanlarda, mitinglere katılma alışkanlığı ve sıklığı daha fazladır (Bkz. Tablo 12).

\section{Seçmenlerin Katıldı̆̆ı Miting ile Mitingdeki Kolektif Ruh Arasındaki İlişki}

MHP mitingindekilerin \%2,5'i, Ak Parti mitingine gelenlerin \%1,6's1 öfkeli; MHP mitingine gelenlerin \%23,9'u, Ak Parti mitingine gelenlerin \%18,8'i cesaretli olduğunu söylerken; Ak Parti mitingine gelenlerin \%23,1'i, MHP mitingine gelenlerin \%22,3'ü umutlu, Ak Parti mitingine gelenlerin \%2,5'i, MHP mitingine gelenlerin \%0,9'u ümitsiz; Ak Parti mitingine gelenlerin \%26,7'si, MHP mitingine gelenlerin \%23,4'ü gururlu olduğunu ifade etmiştir. Buna göre MHP mitinginde olanlarda öfkeli ve cesaretli; Ak Parti mitinginde umutlu, gururlu olanların oranı daha fazladır. Partilere göre ruh hallerinin farklılaşmasından hareketle, mitinglerde kolektif bir ruh hali belirdiğini net bir şekilde söyleyebiliriz. Burada siyasi partilerin ideolojisi, kuruluş amacı ve iddiası, döneme göre sorun ve konulara ilişkin yaklaşım tarzları, güncel kamuoyu mevzuları ve bu konuların toplumsal yansımaları kolektif ruh halinin oluşmasında ve kolektif bir hal almasında etkili olmuş olabilir (Bkz. Tablo 13).

\section{Seçmenlerin Katıldı̆̆ı Miting ile Mitingden Etkilenme Biçimleri Arasındaki İlişki}

Ak Parti mitingine gelenlerin \%49,7'si mitingin oy verme kararını olumlu; \%4,6's1 olumsuz yönde etkilediğini söylerken; \%45,9'u ne olumlu ne de olumsuz yönde bir etkisinin olmadığını ifade etmiştir. Bunun yanı sıra MHP mitingine gelenlerin \%54,2'si 
olumlu, \%2,8'i olumsuz yönde etkilenirken; \%43'ü de olumlu ve/veya olumsuz bir etkisinin olmadığını belirtmiştir. MHP mitingine katılanlardan mitingin oy verme davranışını olumlu yönde etkilediğini söyleyenlerin oranı, Ak Parti mitingine gelenlerden daha fazladır (Bkz. Tablo 14).

\subsection{8: Miting Alanındaki Kolektif Ruh Haline İlişkin Psiko-Politik Bir Tahlil}

\begin{tabular}{lcccccccc}
$\begin{array}{l}\text { Tablo 15: Miting Alanında } \\
\text { (şu anda) Hissettiğiniz En }\end{array}$ & \multicolumn{2}{c}{$\mathbf{1 .}$ Tercih } & \multicolumn{2}{c}{ 2. Tercih } & \multicolumn{2}{c}{ 3. Tercih } & \multicolumn{2}{c}{ Toplam } \\
$\begin{array}{l}\text { Yoğun Üç Duygu } \\
\text { Hangisidir? }\end{array}$ & $\boldsymbol{f}$ & $\mathbf{\%}$ & $\boldsymbol{f}$ & $\mathbf{0}$ & $\boldsymbol{f}$ & $\mathbf{0}$ & $\boldsymbol{f}$ & $\mathbf{\%}$ \\
Mutluyum & $\mathbf{9 7}$ & 32,8 & $\mathbf{9 1}$ & 38,7 & $\mathbf{3}$ & 1,5 & $\mathbf{1 9 1}$ & 26,2 \\
Gururluyum & $\mathbf{1 1}$ & 3,7 & $\mathbf{1 7}$ & 7,2 & $\mathbf{1 5 5}$ & 77,9 & $\mathbf{1 8 3}$ & 25,1 \\
Umutluyum & $\mathbf{1 6}$ & 5,4 & $\mathbf{1 1 4}$ & 48,5 & $\mathbf{3 6}$ & 18,1 & $\mathbf{1 6 6}$ & 22,7 \\
Cesaretliyim & $\mathbf{1 4 8}$ & 50 & $\mathbf{8}$ & 3,4 & $\mathbf{0}$ &, 0 & $\mathbf{1 5 6}$ & 21,3 \\
Öfkeliyim & $\mathbf{1 5}$ & 5,1 & $\mathbf{0}$ &, 0 & $\mathbf{0}$ &, 0 & $\mathbf{1 5}$ & 2,1 \\
Ümitsizim & $\mathbf{5}$ & 1,7 & $\mathbf{4}$ & 1,8 & $\mathbf{3}$ & 1,5 & $\mathbf{1 2}$ & 1,6 \\
Korkuyorum & $\mathbf{1}$ &, 3 & $\mathbf{1}$ &, 4 & $\mathbf{0}$ &, 0 & $\mathbf{2}$ & 0,3 \\
Kıskançlık hissediyorum & $\mathbf{0}$ &, 0 & $\mathbf{0}$ &, 0 & $\mathbf{2}$ & 1,0 & $\mathbf{2}$ & 0,3 \\
Suçluluk hissediyorum & $\mathbf{1}$ &, 3 & $\mathbf{0}$ &, 0 & $\mathbf{0}$ &, 0 & $\mathbf{1}$ & 0,1 \\
Diğer & $\mathbf{2}$ &, 7 & $\mathbf{0}$ &, 0 & $\mathbf{0}$ &, 0 & $\mathbf{2}$ & 0,3 \\
Toplam & $\mathbf{2 9 6}$ & $\mathbf{1 0 0}$ & $\mathbf{2 3 5}$ & $\mathbf{1 0 0}$ & $\mathbf{1 9 9}$ & $\mathbf{1 0 0}$ & $\mathbf{7 3 0}$ & 100
\end{tabular}

Katılımcılardan \%26,2'si miting alanında hissettiği en yoğun hislerden birinin mutluluk, \%25,1'i gurur, \%22,7'si umut, \%21,3'ü cesaret, \%2,1'i öfke, \%1,6's1 ümitsizlik, $\% 03$ 'ü korku, \%0,3'u kıskançlık, \%0,1'i suçluluk olduğunu ifade etmiştir. Bu bağlamda katılımcıların \%4,4'ü öfke, ümitsizlik, korku, kıskançlık ve suçluluk gibi olumsuz duygular içindedir. Miting meydanlarında olumlu ve iyi duygular daha çoğunlukta olsa da, katılımcılardan yaklaşık her yüz kişiden beşinin olumsuz duygular içinde olması dikkat çekicidir. Seçim meydanlarında coşkulu, yüksek sesli ve eğlenceli müziklerin yer yer konserlerin olması; katılımcıların kendilerine benzeyenlerin arasında olduğu hissiyatını taşıması, seçim meydanlarında yörenin kültürü ve sorunlarına göre vaatlerin veriliyor olması çoğunluğunun olumlu duygular içinde olmasına vesile olmuş olabilir. Ancak siyasete ve vaatlere duyulan güvensizlik-şüphe, bıkkınlık ve hayal kırıklığg gibi etkenler de olumsuz duygulara yol açmış olabilir.

\section{Sosyodemografik Faktörler İle Kolektif Ruh Hali Arasındaki İlişki}

Miting alanındaki erkeklerin \%2,1'i, kadınların \%1,9'u öfkeli; erkeklerin \%24,3'ü kadınların \%16,2'si cesaretlidir. Öte yandan kadınların \%30,8'i erkeklerin \%23,6's1 mutlu; kadınların \%23,1'i erkeklerin \%22,6's1 umutlu; kadınların \%26,9'u erkeklerin \%24,1'i gururludur. Cinsiyet açısından miting alanında öfkeli ve cesaretli olan erkek oranı kadın oranından daha fazlayken; (u)mutlu ve gururlu olan kadın oranı erkeklerden daha fazladır (Bkz. Tablo 16). Yaş açısından katılımcıların yaşı arttıkça öfkeli, cesaretli ve gururluların oranı azalmış; umutluların oranı artmıştır (Bkz. Tablo 17). Eğitim durumu açısından ise 
eğitim düzeyi arttıkça mutlu olduğu söyleyenlerin oranı azalmış; cesaretli ve gururlu olduğunu söyleyenlerin oranı artmıştır (Bkz. Tablo 18)

\section{BULGULAR VE DEĞERLENDİRME}

Mitinglerin siyasal katılımdaki rolü ve siyasi rekabetteki önemi her geçen gün, hızla, artmaktadır. Zira günümüzde mitingler, sadece, siyasi aktörlerin belli konular üzerinde halk1 aydınlattığı araçlar değil; sonradan oluşturulacak intiba ve imajın hesaba katıldığ1, katılımcı sayısı ile coşkusunun çeşitli anlamlara geldiği, katılımcılarının kolektif bir ruha büründüğü birer show ve mizansen haline gelmiştir. Siyaset sosyoloji alanında, böylesine önemli bir konunun, yâdsına-gelmiş olması ise son derece manidardır.

Çalışmanın ampirik bölümünden elde edilen verilere göre, katılımcıların yarısından fazlası mitingin düzenleneceği yer ve zaman bilgilerini televizyondan edinirken; yaklaşık her dört kişiden biri ise arkadaşlarından ve sosyal çevresinden öğrenmektedir. Mitinglere insanlar yoğunluğuna göre, partisine destek vermek, partisinin genel başkanı görmek ve mitingi izlemek için katılmaktadır. Partinin genel başkanını, belediye başkan adayını görmek ve partiye destek vermek için gelen kadın oranı erkeklerden; belediye başkan adayına destek vermek, mitingi izlemek için gelen erkek oranı kadınlardan daha fazladır. Yaş arttıkça partinin genel başkanını görmek için katıldığını söyleyenlerin oranı düşmüş; belediye başkan adayına destek olmak için gelenlerin oranı ise artmıştır. Partisine destek vermek ve belediye başkan adayını görmek için mitinge katılanların çoğunluğunu ilköğretim mezunları; partinin genel başkanını görmek ve belediye başkan adayına destek vermek için gelenlerin çoğunluğunu lise mezunları ve mitingi izlemek için gelenlerin çoğunluğunu ise ‘ön lisans ve üstü eğitim düzeyi'ndekiler oluşturmaktadır. Bunun yanı sıra partisine destek vermek için gelenlerin çoğunluğunu ev hanımları, partinin genel başkanını görmek için gelenlerin çoğunluğunu öğrenciler, mitingi izlemek için gelenlerin çoğunluğunu çiftçiler, belediye başkan adayına destek vermek için gelenlerin çoğunluğunu ise işsizler oluşturmaktadır.

Araştırma verilerine göre yaklaşık her on kişiden biri $(\% 12,5)$ mitinginde olduğu partiden farklı bir partiye oy vereceğini söylerken; yüzde \%5,7'si de kararsı olduğunu belirtmiştir. Mitingin tercih ve kararlarını olumsuz etkilediğini söyleyenlerin çoğunluğunu erkekler ve gelir düzeyi düşük olanlar oluşturmaktadır. Farklı partiye oy vereceğini söyleyenleri ve kararsızların çoğunluğu özellikle 18-25 yaş aralığındaki erkeklerdir. Mitinglere katılıma sıklığı arttıkça tercihlerinin değiştiğini söyleyenlerin oranı artmış; mitingin tercihleri üzerinde bir tesiri olmadığını ifade edenlerin oranı ise azalmıştır. Miting meydanlarında yaklaşık her yüz kişiden yirmisinin izleyici-dinleyici (yüzer-gezer seçmen) olduğunu söyleyebiliriz. Bu oran, partinin niteliğine (Kadro-Kitle Partisi), partinin kuruluş amacına, vaatlerine, döneminde ülkenin/yörenin en önemli sorunlarına göre değişse de dikkat çekici bir orandır. Yanı sıra katılımcılardan \%82,6'sının mitinginde olduğu partinin seçimleri kazanacağını düşünmesi, nispeten 'Bandwagon Etkisi'nin göstergesidir. Ayrıca mitingin, katılımcıların düşük bir oranının $(\% 3,7)$ siyasal tercih ve kararları olumsuz yönde etkilediği de bulgular arasındadır.

Seçmen mitinge giderken, hangi partiye oy vereceği ile ilgili peşin hükümle ve hangi partinin kazanacağına ilişkin yerleşik bir kanaatle miting alanına gitmektedir. Ancak miting(ler), her etkiden bağımsız, seçmenlerin kendi isteğiyle katıldığı siyasal araçlar/ortamlar olmasının ötesinde, farklı değişkenlerin ürünüdür. Zira miting alanını dolduracak kitlenin toplanmasında il ve taşra teşkilatları ile muhtar gibi kurum ve kanaat 
önderlerinin etkisi de vardır. Ayrıca medyada yer alan çeşitli haberler, bazı sivil toplum örgütlerinin, sendikaların, meslek-oda ve derneklerin de siyasi parti mitinglerine destek verdiklerini ve toplu katılışlara ön ayak olduklarını iddia etmektedir. Çünkü mitingler, kamuoyu oluşturma işlevinin yanında bilhassa kararsızların ve başka partilere kaçan/kayan taraftarların kazılmasına da katkı sağlamaktadır. Ayrıca mitinge katılım sayısı, miting alanındaki pankart, imge/simge ve diğer göstergeler, katılımcıların coşkusu gibi unsurlar da siyasal açıdan mesaj niteliği taşımaktadır. Parti ve/veya adayların ${ }^{3}$ seçimi kazanıp kazanmamasında miting meydanlarındaki coşkulu ve yoğun kalabalığın etkisi oldukça fazladır. Özellikle miting sonrasında kalabalığın niceliği ve niteliğine ilişkin medyada yer alan haberler, siyasal rekabeti etkilemektedir. Öyle ki; mitingler vaatlerin seçmenlere yüz yüze ifade edildiği ortamlar olmaktan ziyade, partilerin/adayların gövde gösterisi yaptığ1, mevziler kazanıp kaybettiği adeta birer savaş alanıdır. Örneğin Ak Parti’nin 16.06.2013 tarihinde Kazlıçeşme Meydanı'nda düzenlediği “Milli İradeye Sayg1 Mitingi”ne katılanların sayısı uzun süre hem siyasi partiler ${ }^{4}$, hem de kitle iletişim araçları arasında ${ }^{5}$ polemik konusu olmuş ${ }^{6}$; ; bir süre sonra sözlü polemik, katılımcı sayısının, bilimsel yöntemlerle belirlenmesi noktasına ulaşmıştır ${ }^{8}$. Dolayısıyla mitingler seçmenle yüz yüze iletişim kurulduğu alanlar-araçlar olmanın ötesinde, sonradan yaratacağı intiba ve oluşturacağı imajın hesaba katıldığı, birer mizansen gibidir.

Çalışmada meclisteki iki sağ partinin mitingi ve katılımcısına yönelik karşılaştırmalı analiz de yapılmıştır. Araştırmanın örneklemini oluşturan her iki partinin mitingindeki kadın ve erkek oranı birbirine oldukça yakındır. Ak Parti mitinginde "birden fazla kez mitinge katılmış" olanların oranı daha yüksektir. Eğitim düzeyi açısından ise, MHP mitingine katılanların eğitim düzeyi daha yüksektir. Ak Parti mitingine daha çok ev hanımları katılırken; MHP mitingine daha çok özel sektör çalışanları ve kamu personeli katılmıştır. AK parti mitinginde genel başkanı, belediye başkan adayını görmek, mitingi izlemek için gelenlerin oranı; MHP mitinginde ise partisine destek vermek için gelenlerin oranı daha fazladır. MHP mitinginde "mitingine geldiği partiye oy vereceğini" ve mitingin "tercih ve kararlarını olumlu etkilediğini" söyleyenlerin oranı; Ak Parti mitinginde ise kararsızların oranı daha fazladır. Böylece Ak Parti mitinginde izleyici-dinleyicilerin; MHP mitinginde ise taraftarların daha fazla olduğu söylenebilir. Neticede mitinglere katılma amacı ve katılımcıların niteliği partilere, partilerin kimliğine göre farklılık göstermektedir.

Diğer bir açıdan seçim mitinglerinde kolektif bir ruh halinin ortaya çıktığı anlaşılmıştır. Gustave Le Bon, 'Kitleler Psikolojisi' adlı kitabında (1997: 23), "kitleyi meydana getiren bireyler kimler olursa olsun; yaşama biçimleri, içgüdüleri, karakterleri yahut zekâları ister

${ }^{3}$ Boş meydanda tek kişilik miting ${ }^{3}$ (haberturk.com, milliyet.com, hurriyet.com):

${ }^{4}$ Kazlıçeşme meydan savaşı: İki parti İstanbul Kazlıçeşme meydanında birbiri ardına miting yaptı. Hem CHP'nin hem AK Parti'nin mitingi kuşkusuz çok kalabalıktı... Peki hangisi daha fazla kişi topladi? (kanalahaber.com)

5 Boğaziçi Üniversitesi'nden akademisyenler AKP'nin İstanbul mitinginde 295 bin kişinin katıldığını söylerken, Sabah gazetesi '1 milyon 200 bin kişi katıldı' dedi (t24.com)

${ }^{6}$ Kazlıçeşme'de kaç kişi toplandı; 1,2 milyon kişi mi, yoksa dörtte biri mi? (t24.com)

7 Mitinge kaç kişi geldiği tespit edilecek: AK Parti Mersin İl Teşkilatı'nın yarın Başbakan Recep Tayyip Erdoğan'ın Mersin'de düzenleyeceği mitinge kaç partilinin katılacağını tespit etmek amaciyla 'barkod' sistemi uygulayacağı bildirildi (iha.com.tr).

8 Boğaziçi'li akademisyenler Kazlıçeşme'deki katılımcı sayısını hesapladı: AKP İl Başkanlığının 1 milyon partiliyi toplama iddiasıyla yola çıktığı Kazlıçeşme mitingine kaç kişi katıldı? Boğaziçi Üniversite profesörleri AKP'nin Kazlıçeşme mitingine kaç kişinin katıldığını hesapladı (radkial.com.tr), (yurtgazetesi.com). 
benzer, ister ayrı olsun, kalabalık haline gelmiş olmalarının onlara bir nevi kolektif ruh aşıladığını" ifade eder. Çalışmanın verilerine göre MHP mitinginde öfkeli ve cesaretlilerin; Ak Parti mitinginde ise umutlu, gururluların oranı daha fazladır. Miting meydanlarında olumlu/iyi duygular içinde olanlar çoğunlukta olsa da, yaklaşık her yüz kişiden beşi olumsuz duygular içindedir. (a) Seçim meydanlarında coşkulu, yüksek sesli ve eğlenceli müziklerin kullanılması, yer yer konserlerin düzenlenmesi; (b) katılımcıların meydandaki topluluğa benzediği hissiyatı taşıması ve etrafındakilere aidiyet duygusuyla bağlı olması; (c) vaatlerin yörenin kültürü ve sorunlarına ilişkin olması ve böylece sorunların çözülüyor olduğuna dair beklenti içine girilmesi; (d) miting meydanındaki katılımcıların kitle psikolojisiyle abartılı heyecan ve coşku duyması gibi faktörlerler çoğunluğun içinde bulunduğu ruh halini olumlu duygularla tanımlamasına sebep olmuş olabilir. Öte yandan, (i) siyasete duyulan güvensizlik; (ii) vaatlerin yerine getirilmemesinin yarattığı bıkkınlık ve/veya şüphe; (iii) güvenlik endişesi; (iv) herhangi bir siyasi tarafın mensubu veya taraftarı olarak yaftalanma-etiketlenme korkusu gibi nedenler ise olumsuz duygulara yol açmış olabilir. Sosyodemografik açıdan erkekler miting alanında hissettiği duyguları daha çok öfkeli ve cesaretli; kadınlar ise $(u)$ mutlu ve gururlu şeklinde tarif etmiştir. Yaş arttıkça içinde bulunduğu ruh halini öfkeli, cesaretli olarak betimleyenlerin oranı azalmış; umutlu olarak tanımlayanların oranı artmıştır. Eğitim arttıkça mutlu olduğunu söyleyenlerin oranı azalmış; cesaretli ve gururlu olduğunu söyleyenlerin oranı ise artmıştır.

Hülasa seçim mitingleri nevi-şahsına münhasır değişkenleri ve bileşenleri olan bir siyasal katılım enstrümanıdır. Son dönemlerde önemi artan ve sıkça kullanılan mitingler, geleneksel formundan da gittikçe uzaklaşmaktadır. Artık iyi bir miting stratejisi yürütemeyen, yaptığı mitingi iyi pazarlayamayan adayların/partilerin siyasal alanda rekabet edebilmesi mümkün görünmemektedir. Mevcut durum, mitinglerin artan öneminin akademik açıdan derinlemesine ele alınmasını elzem hale getirmektedir. Böylece oluşacak bilgi havuzu sayesinde mitinglerin sosyo politiği daha iyi analiz edilebilecek ve özgün bir miting sosyolojisi oluşacaktır.

\section{KAYNAKÇA}

Anık, Cengiz (2000), Siyasal İkna, Vadi yayınları, Ankara.

Aybek, Şahin (2008), Siyaset Sosyolojisine Giriş, Maya Akademi Yayın Dağıtım, Ankara.

Çetin, Halis (2012), Siyaset Bilimi (Önsöz), Orion Kitabevi, Ankara.

Emiroğlu, Akif (2006), Toplumbilimsel Siyasa, Siyasal Sosyolojiye Giriş, Ekin Kitabevi, 2006.

Eroğlu Cem (2012a), Siyaset, Haz: Gökhan Atılgan, E. Attila Aytekin, Siyaset Bilimi, Kavramlar, İdeolojiler, Disiplinler Arası İlişkiler, Yordam Kitap Yayınları, İstanbul.

Eroğlu Cem (2012b), Siyasal Katılma, Haz: Gökhan Atılgan, E. Attila Aytekin, Siyaset Bilimi, Kavramlar, İdeolojiler, Disiplinler Arası İlişkiler, Yordam Kitap Yayınları, İstanbul.

Heywood, Andrew (2007), Siyaset, Adres Yayınları, Ankara.

Kahraman, Ahmet Burak (2011), Siyasal Katılımın Sosyolojik Analizi, Çizgi Kitabevi, Konya.

Kapani, Münci (2009), Politika Bilimine Giriş, Bilgi Yayınevi Yayınları, Ankara. 
Kışlalı, Ahmet Taner (2010), Siyasal Sistemler, Siyasal Çatışma ve Uzlaşma, İmge Kitabevi, 7. Bask1, Ankara.

Le Bon, Gustave (1997), Kitleler Psikolojisi, Hayat Yayınları, İstanbul.

Manza, Jeff, Brooks, Clem ve Michael Sauder (2010), Para, Katılım ve Oylar, Çev: Koray Büyüktuncer ve İsmail Karatekin, Der: Thomas Janoski, Robert Alford, Alexander Hicks, Mildred A. Schwartz, Siyaset Sosyolojisi, Phoenix Yayınları, Ankara.

Mosca, Gaetano (2013), Siyaset Biliminin Temelleri, Bil Ofset Matbaacılik, Ankara. Ankara.

Özer, İnan (2004), Kentleşme, Kentlileşme ve Siyasal Değişme, Ekin Kitabevi,

Roskin Michael, G., Robert L. Cord, James A. Medeiros, Walter S. Jones, (2013), Siyaset Bilimi, Çev: Atilla Yayla, 1. Baskı, Adres Yayınları: Ankara.

Taşdelen, Musa (2011), Siyaset Sosyolojisi, Siyasi İktidar, Siyasi Sistem, Siyasi Davranış, Kocav Yayınları, İstanbul.

Tokgöz, Oya (2008), Siyasal İletişimi Anlamak, İmge Kitabevi, Ankara.

Tosun, Gülgün ve Tepecikoğlu, Onur (2012) Siyasi Partiler, Siyasi Katılım ve Propaganda, Ed: Halis Çelik: Siyaset Bilimi, Orion Kitabevi, Ankara.

Türköne, Mümtazer (2012), Siyaset, Etkileşim Yayınları, İstanbul.

Üste, Bahar (2011), Siyaset Bilimi, Beta Yayınları, İstanbul.

Weakliem, David, L., (2010), Kamuoyu, Siyasi Tutumlar ve İdeoloji, Çev: Duygu Danış, Der: Thomas Janoski, Robert Alford, Alexander Hicks, Mildred A. Schwartz, Siyaset Sosyolojisi, Phoenix Yayınları, Ankara.

\section{Internet Siteleri}

http://t24.com.tr/haber/akademisyenler-kazlicesmede-maksimum-500-bin-vardi-sabah1-milyon-200-bin-kisi-vardi,232164 yapti

http://www.haberturk.com/gundem/haber/1144063-bos-meydanda-tek-kisilik-miting-

http://www.hurriyet.com.tr/bos-meydanda-tek-kisilik-miting-40005261

http://www.kanalahaber.com/haber/gundem/kazlicesme-meydan-savasi-76884/

http://www.mevzuat.gov.tr/MevzuatMetin/1.5.2911.pdf

http://www.milliyet.com.tr/bos-meydanda-tek-kisilik-

miting/siyaset/detay/2136881/default.htm

http://www.radikal.com.tr/politika/bogazicili-akademisyenler-kazlicesmedekikatilimci-sayisini-hesapladi-1137905/

http://www.tdk.gov.tr/index.php?option=com_yanlis\&view=yanlis\&kelimez=298

http://www.turkcebilgi.com/miting\#bilgi

http://www.yurtgazetesi.com.tr/gundem/akp-mitingine-kac-kisi-katildi-h36851.html 
EK (Tablolar Listesi)

Tablo 10: Seçmenlerin Katıldığı Miting ile Oy Vereceği Parti Arasındaki İlişki

\begin{tabular}{|c|c|c|c|c|c|c|}
\hline & & & \multicolumn{4}{|c|}{$\begin{array}{l}\text { Önümüzdeki Mahalli seçimlerde hangi partiye oy } \\
\text { vereceksiniz? }\end{array}$} \\
\hline & & & $\begin{array}{l}\text { Mitinginde } \\
\text { olduğum partiye }\end{array}$ & $\begin{array}{l}\text { Farklı bir } \\
\text { partiye }\end{array}$ & Kararsızım & Toplam \\
\hline \multirow{4}{*}{$\begin{array}{l}\text { Bulunduğunuz } \\
\text { miting }\end{array}$} & \multirow{2}{*}{$\begin{array}{l}\text { Ak } \\
\text { Parti }\end{array}$} & f & 120 & 22 & 12 & 154 \\
\hline & & $\%$ & 77,9 & 14,3 & 7,8 & 100 \\
\hline & \multirow{2}{*}{ MHP } & f & 122 & 15 & 5 & 142 \\
\hline & & $\%$ & 85,9 & 10,6 & 3,5 & 100 \\
\hline \multirow{2}{*}{ Toplam } & & f & 242 & 37 & 17 & 296 \\
\hline & & $\%$ & 81,8 & 12,5 & 5,7 & 100 \\
\hline
\end{tabular}

Tablo 11: Seçmenlerin Katıldığı Miting ile Katılım Nedeni Arasındaki İlişki

\begin{tabular}{|c|c|c|c|c|c|c|c|c|c|}
\hline & & & \multicolumn{7}{|c|}{ Mitinglere neden katılırsınız? } \\
\hline & & & $\begin{array}{c}\text { Genel } \\
\text { başkanı } \\
\text { görmek }\end{array}$ & $\begin{array}{c}\text { Partime } \\
\text { destek } \\
\text { vermek }\end{array}$ & $\begin{array}{c}\text { Başkan } \\
\text { adayın } \\
\text { görmek }\end{array}$ & $\begin{array}{c}\text { Başkan } \\
\text { adayina } \\
\text { destek } \\
\text { vermek }\end{array}$ & $\begin{array}{c}\text { Sadece } \\
\text { izlemek } \\
\text { ve merak } \\
\text { gidermek }\end{array}$ & Diğger & Toplam \\
\hline \multirow{4}{*}{$\begin{array}{l}\text { Mitingin } \\
\text { Yapıldığı } \\
\text { Parti }\end{array}$} & \multirow{2}{*}{$\begin{array}{l}\text { Ak } \\
\text { Parti }\end{array}$} & f & 50 & 68 & 7 & 6 & 21 & 3 & 155 \\
\hline & & $\%$ & 32,3 & 43,9 & 4,5 & 3,9 & 13,5 & 1,9 & 100 \\
\hline & \multirow{2}{*}{ MHP } & f & 13 & 115 & 3 & 8 & 6 & $\mathbf{0}$ & 145 \\
\hline & & $\%$ & 9,0 & 79,3 & 2,1 & 5,5 & 4,1 &, 0 & 100 \\
\hline \multirow{2}{*}{ Toplam } & & $\mathbf{f}$ & 63 & 183 & 10 & 14 & 27 & 3 & 300 \\
\hline & & $\%$ & 21,0 & 61,0 & 3,3 & 4,7 & 9,0 & 1,0 & 100 \\
\hline
\end{tabular}

Tablo 12: Seçmenlerin Katıldığı Miting ile Katılım Sıklığı Arasındaki İliş̧ki

Daha önceden kaç kere mitinge katıldınız?

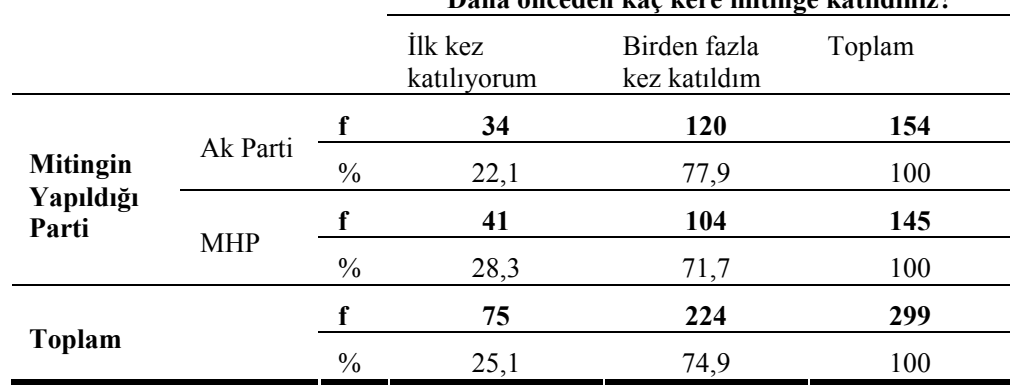


Tablo 13: Seçmenlerin Katıldığı Miting ile Oluşan Kolektif Ruh Arasındaki İlişki

Miting alanında hissettiğiniz en yoğun üç duygu hangisidir

\begin{tabular}{|c|c|c|c|c|c|c|c|c|c|c|c|c|c|}
\hline & & & 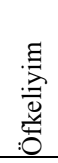 & 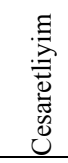 & 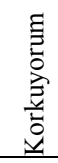 & $\underset{\sum}{\stackrel{\Xi}{\Xi}}$ & $\frac{\breve{J}}{3}$ & $\underset{\Xi}{\Xi}$ & 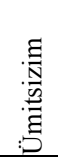 & $\underset{\Xi}{\Xi}$ & 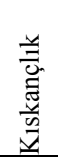 & $\begin{array}{l}\bar{D} \\
.000 \\
\end{array}$ & $\begin{array}{c}\frac{\Xi}{0} \\
\frac{0}{0} \\
\text { อ }\end{array}$ \\
\hline \multirow{4}{*}{$\begin{array}{l}\text { Mitingin } \\
\text { Yapıldığı } \\
\text { Parti }\end{array}$} & \multirow{2}{*}{$\begin{array}{l}\text { Ak } \\
\text { Parti } \\
\end{array}$} & $f$ & 6 & 68 & 1 & 95 & $\mathbf{0}$ & 84 & 9 & 97 & 1 & 2 & 363 \\
\hline & & $\%$ & 1,6 & 18,8 & 0,3 & 26,1 & 0,0 & 23,1 & 2,5 & 26,7 & 0,3 & 0,6 & 100 \\
\hline & \multirow{2}{*}{ MHP } & $f$ & 9 & 88 & 1 & 96 & 1 & 82 & 3 & 86 & 1 & 0 & 367 \\
\hline & & $\%$ & 2,5 & 23,9 & 0,3 & 26,1 & 0,3 & 22,3 & 0,9 & 23,4 & 0,3 & 0,0 & 100 \\
\hline \multirow{2}{*}{ Toplam } & & $f$ & 15 & 156 & 2 & 191 & 1 & 166 & 12 & 183 & 2 & 2 & 730 \\
\hline & & $\%$ & 2,1 & 21,3 & 0,3 & 26,2 & 0,1 & 22,7 & 1,6 & 25,1 & 0,3 & 0,3 & 100 \\
\hline
\end{tabular}

Tablo 14: Seçmenlerin Katıldığı Miting ile Mitingin Tercihleri Etkileme Biçimi Arasındaki İlișki

\begin{tabular}{|c|c|c|c|c|c|c|}
\hline & & & \multicolumn{4}{|c|}{ Miting oy verme kararınızı ne yönde etkiledi? } \\
\hline & & & Olumlu & Olumsuz & Ne olumlu, ne olumsuz & Toplam \\
\hline \multirow{4}{*}{$\begin{array}{l}\text { Mitingin } \\
\text { Yapıldığı } \\
\text { Parti }\end{array}$} & \multirow{2}{*}{ Ak Parti } & f & 76 & 7 & 70 & 153 \\
\hline & & $\%$ & 49,7 & 4,6 & 45,9 & 100 \\
\hline & \multirow{2}{*}{ MHP } & $\mathbf{f}$ & 77 & 4 & 61 & 142 \\
\hline & & $\%$ & 54,2 & 2,8 & 43,0 & 100 \\
\hline \multirow{2}{*}{ Toplam } & & f & 153 & 11 & 131 & 295 \\
\hline & & $\%$ & 51,9 & 3,7 & 44,4 & 100 \\
\hline
\end{tabular}

Tablo 16: Cinsiyet İle Seçmenin Miting Alanında En Yoğun Hissettiği Duygu Arasındaki İlişki

Miting alanında hissettiğiniz en yoğun üç duygu hangisidir?

\begin{tabular}{|c|c|c|c|c|c|c|c|c|c|c|c|c|c|}
\hline & & & 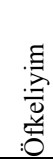 & 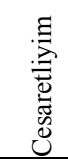 & 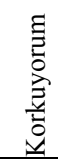 & $\underset{\sum}{\stackrel{\Xi}{\Xi}}$ & 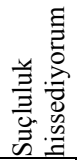 & 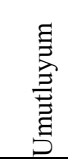 & 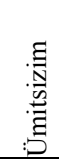 & $\underset{\Xi}{\Xi}$ & 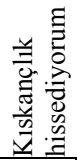 & $\begin{array}{l}\dot{\vec{d}} \\
\overrightarrow{0}\end{array}$ & $\frac{\Xi}{0}$ \\
\hline \multirow{4}{*}{ Cinsiyet } & \multirow{2}{*}{ Kadın } & $f$ & 5 & 42 & 0 & 80 & $\mathbf{0}$ & 60 & 3 & 70 & $\mathbf{0}$ & $\mathbf{0}$ & 260 \\
\hline & & $\%$ & 1,9 & 16,2 & 0,0 & 30,8 & 0,0 & 23,1 & 1,1 & 26,9 & 0,0 & 0,0 & 100 \\
\hline & \multirow{2}{*}{ Erkek } & $f$ & 10 & 114 & 2 & 111 & 1 & 106 & 9 & 113 & 2 & 2 & 470 \\
\hline & & $\%$ & 2,1 & 24,3 & 0,4 & 23,6 & 0,2 & 22,6 & 1,9 & 24,1 & 0,4 & 0,4 & 100 \\
\hline Toplam f & & & 15 & 156 & 2 & 191 & 1 & 166 & 12 & 183 & 2 & 2 & 730 \\
\hline Toplam \% & & & 2,1 & 21,4 & 0,3 & 26,1 & 0,1 & 22,7 & 1,6 & 25,1 & 0,3 & 0,3 & 100 \\
\hline
\end{tabular}

Tablo 17: Yaş İle Seçmenin Miting Alanında En Yoğun Hissettiği Duygu Arasındaki İlişki 


\begin{tabular}{|c|c|c|c|c|c|c|c|c|c|c|c|c|c|}
\hline & & & 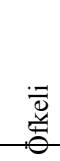 & 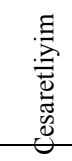 & 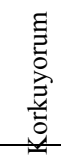 & 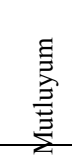 & 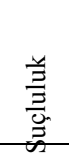 & 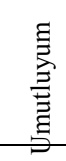 & 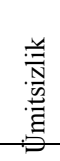 & $\underset{\Xi}{\stackrel{\Xi}{\Xi}}$ & 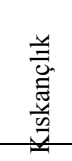 & 离 & $\frac{\Xi}{\frac{\Xi}{2}}$ \\
\hline \multirow{6}{*}{ Yaş } & \multirow{2}{*}{$\begin{array}{r}18- \\
25\end{array}$} & f & 7 & 54 & 0 & 54 & 0 & 45 & 4 & 58 & 1 & 0 & 223 \\
\hline & & $\% 2$ & 3,2 & 24,2 & 0,0 & 24,2 & 0,0 & 20,2 & 1,8 & 26 & 0,4 & 0,0 & 100 \\
\hline & \multirow{2}{*}{$\begin{array}{r}26- \\
45\end{array}$} & f & 6 & 64 & 1 & 88 & 0 & 75 & 3 & 78 & 0 & 1 & 316 \\
\hline & & $\% 2$ & 1,9 & 20,2 & 0,3 & 27,9 & 0,0 & 23,8 & 0,9 & 24,7 & 0,0 & 0,3 & 100 \\
\hline & \multirow{2}{*}{$\begin{array}{l}46 \\
\text { ve } \\
\text { üstü }\end{array}$} & f & 2 & 38 & 1 & 49 & 1 & 46 & 5 & 47 & 1 & 1 & 191 \\
\hline & & $\% 2$ & 1 & 19,9 & 0,5 & 25,6 & 0,5 & 24,1 & 2,7 & 24,7 & 0,5 & 0,5 & 100 \\
\hline \multirow{2}{*}{\multicolumn{2}{|c|}{ Toplam }} & f & 15 & 156 & 2 & 191 & 1 & 166 & 12 & 183 & 2 & 2 & 730 \\
\hline & & $\% 2$ & 2,1 & 21,4 & 0,3 & 26,1 & 0,1 & 22,8 & 1,6 & 25 & 0,3 & 0,3 & 100 \\
\hline
\end{tabular}

Tablo 18: Eğitim İle Seçmenin Miting Alanında En Yoğun Hissettiği Duygu Arasındaki İlișki

Miting alanında hissettiğiniz en yoğun üç duygu hangisidir?

\begin{tabular}{|c|c|c|c|c|c|c|c|c|c|c|c|c|}
\hline & & $\underset{\sum}{\stackrel{\Xi}{\Xi}}$ & $\underset{\Xi}{\Xi}$ & $\underset{\Xi}{\Xi}$ & 离 & 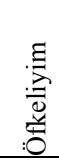 & 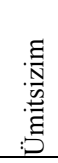 & 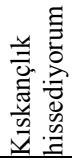 & 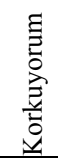 & 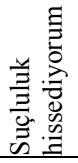 & $\begin{array}{l}\dot{\bar{D}} \\
.000 \\
0\end{array}$ & $\frac{\Xi}{\frac{\pi}{7}}$ \\
\hline \multirow{2}{*}{ İlköğretim } & $f$ & 80 & 60 & 62 & 56 & 4 & 4 & 1 & 2 & 1 & 0 & 270 \\
\hline & $\%$ & 29,6 & 22,2 & 23 & 20,7 & 1,5 & 1,5 & 0,4 & 0,7 & 0,4 & 0,0 & 100 \\
\hline \multirow{2}{*}{ Lise } & $f$ & 60 & 63 & 51 & 50 & 6 & 5 & 0 & 0 & 0 & 0 & 235 \\
\hline & $\%$ & 25,6 & 26,9 & 21,7 & 21,2 & 2,5 & 2,1 & 0,0 & 0,0 & 0,0 & 0,0 & 100 \\
\hline \multirow{2}{*}{$\begin{array}{l}\text { Ön lisans } \\
\text { ve Üstü }\end{array}$} & $f$ & 51 & 60 & 53 & 50 & 5 & 3 & 1 & 0 & 0 & 2 & 225 \\
\hline & $\%$ & 22,7 & 26,7 & 23,6 & 22,2 & 2,2 & 1,4 & 0,4 & 0,0 & 0,0 & 0,8 & 100 \\
\hline \multicolumn{2}{|l|}{ Toplam f } & 191 & 183 & 166 & 156 & 15 & 12 & 2 & 2 & 1 & 2 & 730 \\
\hline \multicolumn{2}{|l|}{ Toplam \% } & 26,2 & 25 & 22,7 & 21,4 & 2 & 1,7 & 0,3 & 0,3 & 0,1 & 0,3 & 100 \\
\hline
\end{tabular}

